\title{
Protecting the Constitution from the People: Juricentric Restrictions on Section Five Power ${ }^{\dagger}$
}

\author{
ROBERT C. POST* \\ REVA B. SIEGEL**
}

"America is its Constitution."

In a recent string of decisions invalidating federal civil rights legislation, the Supreme Court has repeated the simple but powerful message: "The Constitution belongs to the courts." Beginning from the premise that Congress's "authority is limited to those powers enumerated in the Constitution," the decisions emphasize that it is the Court's special responsibility to mark where Congress "has exceeded its constitutional bounds." 3 The Court has insisted that it must impose "judicially enforceable outer limits"4 on Congress's enumerated powers, even at the cost of considerable "legal uncertainty."

These decisions break with the judicial practice of the last half century, when the Court employed doctrines of deference to vindicate democratic values in constitutional interpretation, defining the scope of federal power in terms that gave great weight to Congress's judgments about the nation's needs and interests. No longer does the Court emphasize the respect due to the constitutional judgments of a coequal and democratically elected branch of government. Now it claims that only the judiciary can define the meaning of the Constitution.

${ }^{\dagger}$ Copyright 2002 by Robert C. Post and Reva B. Siegel. All rights reserved. We are grateful for the advice and critique of good colleagues and friends, including Bruce Ackerman, Jesse Choper, Michael Dorf, Mel Eisenberg, Owen Fiss, Willy Forbath, Phil Frickey, Barry Friedman, Howard Gillman, Jim Gordley, Linda Greenhouse, Stephen Griffin, Ian Haney-Lopez, Jill Hasday, Larry Kramer, Linda Krieger, Marty Lederman, Sandy Levinson, Ira C. Lupu, John Manning, Rachel Moran, William Marshall, David McGowan, Paul Mishkin, William Nelson, and Sambhav Sankar, and Jed Shugerman.

- Alexander F. and May T. Morrison Professor of Law, University of California at Berkeley (Boalt Hall).

* Nicholas deB. Katzenbach Professor of Law, Yale Law School.

1. Sign on antiwar protest wall, Point Reyes Station, California, Jan. 27, 2002.

2. United States v. Lopez, 514 U.S. 549, 566 (1995).

3. United States v. Morrison, 529 U.S. 598, 607 (2000). For the Court's decisions limiting congressional power under the Commerce Clause, see United States v. Morrison, 529 U.S. 598 (2000); United States v. Lopez, 514 U.S. 549 (1995). Cf. Solid Waste Agency of N. Cook County v. U. S. Army Corps of Eng'rs, 531 U.S. 159 (2001); Jones v. United States, 529 U.S. $848(2000)$. For the Court's decisions limiting congressional power under Section 5 of the Fourteenth Amendment, see Board of Trustees of the University of Alabama v. Garrett, 531 U.S. 356 (2001); United States v. Morrison, 529 U.S. 598 (2000); Kimel v. Florida Board of Regents, 528 U.S. 62 (2000); Florida Prepaid Postsecondary Education Expense Board v. College Savings Bank, 527 U.S. 627 (1999); City of Boerne v. Flores, 521 U.S. 507 (1997).

4. Morrison, 529 U.S. at 610; Lopez, 514 U.S. at 566.

5. Lopez, 514 U.S. at 566. The Court warns that "any possible benefit from eliminating this 'legal uncertainty' would be at the expense of the Constitution's system of enumerated powers." Id. The Court has evidently been more determined to remind Congress that courts enforce constitutional limits on national power than to identify the exact nature of such limits. 
These remarkable decisions reflect not only the objective of protecting states from an overreaching national government, which sounds in federalism, but also the distinct theme of separation of powers. At issue is the "cardinal rule of constitutional law" that "ever since Marbury this Court has remained the ultimate expositor of the constitutional text." The Court has been particularly skeptical of Congress's efforts to exercise its power under Section 5 of the Fourteenth Amendment "to enforce, by appropriate legislation, the provisions of this article." Congressional lawmaking under Section 5 raises especially knotty issues of separation of powers, because Section 5 legislation necessarily involves congressional judgments about the meaning of Section 1 of the Fourteenth Amendment.

The Rehnquist Court has increasingly come to regard Section 5 legislation as challenging the Court's ultimate authority to interpret the Fourteenth Amendment. In a series of cases that began with City of Boerne v. Flores ${ }^{8}$ in 1997, and that culminated two Terms ago in Board of Trustees of the University of Alabama v. Garrett, ${ }^{9}$ the Court has imposed ever more restrictive conditions on Congress's ability to exercise its Section 5 power. These restrictions reflect the Court's growing apprehension that Congress may be playing too large "a role in interpreting and applying the Constitution." 10 The decisions express with growing clarity the Court's claim to an exclusive authority to interpret the Constitution.

This article explores the understanding of the Constitution that underlies the Court's claim to such exclusive authority. The Court's recent decisions invalidating Section 5 legislation invoke the Constitution as a document that speaks only to courts. We call this vision the "juricentric Constitution." The juricentric Constitution imagines the judiciary as the exclusive guardian of the Constitution. It allows the Court's coordinate branches to enforce the Constitution only insofar as they enforce judicial interpretations of constitutional meaning, an approach that radically circumscribes Congress's power under Section 5 of the Fourteenth Amendment. The Court justifies these restrictions in a way that fundamentally misdescribes American constitutional culture, as we show by examining constitutional practice during the closing decades of the twentieth century, when the Court regularly looked to Congress to anchor and orient its constitutional judgments. We advance this argument in three stages.

Part I of this Article discusses the recent decision of Board of Trustees of the University of Alabama v. Garrett, ${ }^{11}$ which most fully exemplifies the Court's vision of the juricentric Constitution. We show how this juricentric conception of our constitutional order thoroughly affects Garrett's reasoning and pervasively informs the Court's restructuring of Section 5 jurisprudence to restrict Congress's role. Garrett subjects Section 5 legislation to close scrutiny, prohibiting Congress from exercising its power to enforce the Fourteenth Amendment unless Congress first documents conduct that a court might find represents a pattern of constitutional violations. By requiring Congress to act like a court before exercising legislative authority to enact a Section 5 statute, Garrett imposes a substantial and improper burden on congressional

6. Morrison, 529 U.S. at 616 n.7.

7. U.S. CONST. amend. XIV, $\S 5$.

8. 521 U.S. 507 (1997).

9. 531 U.S. 356 (2001).

10. Morrison, 529 U.S. at 616 n. 7 .

11. 531 U.S. 356 (2001). 
power to enforce civil rights.

In Part II, we analyze the Court's justification for imposing this burden on Congress's power to enact Section 5 legislation. The Court believes that Congress threatens the Court's role as the "ultimate expositor of the constitutional text" 12 when Congress apprehends constitutional violations in ways that differ from the Court's. The Court thus sets up a sharp opposition between its own "legal" constructions of the Constitution and Congress's "political" understandings, which the Court uses to justify excluding the political branches of government from matters of constitutional interpretation. The dichotomy is false and fundamentally misconceives the character of the Court's own jurisprudence. The Court's own authority to interpret the Constitution has both legal and political dimensions. As the history of both the New Deal and the Second Reconstruction illustrate, the Court must engage in a continual dialogue with the political understandings of the nation in order effectively to exercise its own constitutional authority. Once we reconceive the nature of the Court's constitutional jurisprudence, we can better theorize its relationship with Congress.

In Part III, we explore historical alternatives to the Rehnquist Court's vision of the juricentric Constitution. In the 1960 s, and for decades thereafter, the Court forcefully defended its prerogative to declare the meaning of the Constitution and simultaneously constructed doctrine that encouraged Congress to exercise its Section 5 power. The major civil rights statutes of the Second Reconstruction were enacted within this constitutional environment. The Court upheld this legislation on grounds that deliberately ambiguated the exact relationship between Section 5 power and the Court's own interpretations of Section 1 of the Fourteenth Amendment. This ambiguity established the possibility of a lively and consequential dialogue between the Court's legal interpretation of the Constitution and the constitutional ideals democratically embraced by the nation.

Although the Rehnquist Court is certainly not obliged to preserve these constitutional arrangements, we argue that its recent decisions, exemplified by Garrett, are fundamentally indifferent to the subtle but fundamental interconnections between the constitutional dimensions of our political life and the democratic dimensions of our constitutional culture. Garrett's dissenting Justices passionately voice such concerns, but in the end this is a question to which Congress itself must speak.

The issue in Garrett was whether Congress had power under Section 5 of the Fourteenth Amendment to create damage actions against states to enforce Title I of the Americans with Disabilities Act of 1990 ("ADA"). ${ }^{13}$ Title I prohibits employers, including states, from "discriminat[ing] against a qualified individual with a disability because of the disability of such individual in regard to job application procedures, the hiring, advancement, or discharge of employees, employee compensation, job training, and other terms, conditions, and privileges of employment." ${ }^{14}$ The plaintiffs in Garrett

12. Morrison, 529 U.S. at 616 n.7.

13. Pub. L. No. 101-336, 104 Stat. 327 (codified as amended at 42 U.S.C. $\S \S 12,101-12,213$ ).

14. Garrett, 531 U.S. at 360-61 (quoting 42 U.S.C. $\$ \$ 12111(2),(5),(7), 12112(a)(2000)$ ). Garrett was authored by Chief Justice Rehnquist, whose opinion was joined by four other 
sued the University of Alabama for damages, alleging that the University had discriminated in violation of Title I. The University defended by arguing that the plaintiffs' suits were barred by the sovereign immunity recognized in the Eleventh Amendment.

Recent decisions of the Court have made clear that "Congress may not . . . base its abrogation of the States' Eleventh Amendment immunity upon the powers enumerated in Article I," except when it acts "pursuant to a valid exercise of its $\S 5$ power." 15 The scope of Section 5 power has thus come to define the circumstances in which federal legislation can authorize private damage suits against states that have not waived their Eleventh Amendment immunity.

Section 5 vests in Congress the "power to enforce, by appropriate legislation, the provisions"16 of Section 1 of the Fourteenth Amendment. Until recently, the Court reasoned about Section 5 in terms of the settlement reached as a result of the constitutional crises of the New Deal. The Court announced in Katzenbach $v$. Morgan $^{17}$ that it would accord Congress's judgment about the scope of Section 5 power the same deference that it accorded Congress's judgment about the scope of its Commerce Clause power, ${ }^{18}$ while at the same time reserving authority to determine whether any particular exercise of Section 5 power violated constitutional rights. ${ }^{19}$

The Court began to dismantle this analytic framework during the 1990s. Although themes of federalism have been prominent in this transformation, the Court justified its

Justices. Justice Kennedy penned a separate concurrence, joined by Justice O'Connor. Justice Breyer, joined by Justices Stevens, Souter, and Ginsburg, dissented.

15. Garrett, 531 U.S. at 364 (internal citations and quotations omitted). See, Seminole Tribe of Fla. v. Florida, 517 U.S. 44 (1996); Fitzpatrick v. Bitzer, 427 U.S. 445 (1976). For a brief discussion of the nature of Eleventh Amendment immunity, see Robert C. Post \& Reva B. Siegel, Equal Protection by Law: Federal Antidiscrimination Legislation After Morrison and Kimel, 110 Yale L.J. 441, 450-51 (2000).

16. U.S. CONST. amend. XIV, $\$ 5$.

17. 384 U.S. 641 (1966).

18. Id. at $652 \mathrm{n} .11$. Most generally, Katzenbach held:

By including $\S 5$ the draftsmen sought to grant to Congress, by a specific provision applicable to the Fourteenth Amendment, the same broad powers expressed in the Necessary and Proper Clause, Art. I, s 8, cl. 18. The classic formulation of the reach of those powers was established by Chief Justice Marshall in McCulloch $v$. Maryland, 4 Wheat. 316, 421:

Let the end be legitimate, let it be within the scope of the constitution, and all means which are: appropriate, which are plainly adapted to that end, which are not prohibited, but consist with the letter and spirit of the constitution, are constitutional....

Thus the McCulloch v. Maryland standard is the measure of what constitutes "appropriate legislation" under $\S 5$ of the Fourteenth Amendment. Correctly viewed, $\S 5$ is a positive grant of legislative power authorizing Congress to exercise its discretion in determining whether and what legislation is needed to secure the guarantees of the Fourteenth Amendment.

Id. at 650-51. See also Archibald Cox, The Supreme Court, 1966 Term-Foreword: Constitutional Adjudication and the Promotion of Human Rights, 80 HARV. L. REV. 91,119 (1966).

19. Katzenbach, 384 U.S. at $651 \mathrm{n}$.10. This reservation came to be known as the so-called "ratchet" argument. For a discussion of the "ratchet" argument, see infra notes 170-73. 
retreat from Katzenbach in terms that primarily focused on separation of powers. ${ }^{20}$ In 1997 in City of Boerne v. Flores, ${ }^{21}$ the Court expressed its concern that Congress might use Section 5 legislation to arrogate to itself authority to redefine the substantive content of Section 1 guarantees. Boerne held that "judicial authority"22 to interpret Section 1 must be safeguarded from the encroachment of "legislation which alters the meaning",23 of the Constitution, on the theory that such legislation "cannot be said to be enforcing the" ${ }^{24}$ Constitution. Boerne accordingly required that Section 5 legislation be congruent and proportional to judicially ascertained rights. The Court explained that the test of congruence and proportionality would locate the point at which Section 5 legislation ceased to "remedy or prevent unconstitutional actions" and became instead "substantive in operation and effect." 25

This view of separation of powers allocates the task of constitutional interpretation exclusively to courts, attributing to Congress the subsidiary role of enforcing judicially articulated constitutional rights. Whereas the Court's earlier Section 5 decisions had understood separation of powers to warrant judicial deference in order to coordinate the constitutional judgments of two equal branches of the federal government, Boerne, by contrast, imagined separation of powers as requiring functional differentiation, so that the Court's legal expertise endowed it with exclusive authority to interpret the Constitution. Boerne advanced claims of expertise to justify limiting Congress's Section 5 power. It viewed the prospect of legislative encroachment on judicial prerogatives as more worrisome than the prospect of judicial encroachment on legislative prerogatives.

Yet Boerne also suggested that Congress ought to enjoy a fair degree of independent responsibility in implementing its Section 5 power. Although Boerne struck down the Religious Freedom Restoration Act ("RFRA"), ${ }^{26}$ it nevertheless emphasized the "broad terms" ${ }^{27}$ of Section 5 power and stressed the "deference" 28 and

20. Underlying the Court's growing antagonism to Section 5 power lie two distinct values: federalism and separation of powers. We have discussed the value of federalism elsewhere, and we will not dwell upon it here. See Post \& Siegel, supra note 15, at 486-513.

21. 521 U.S. 507 (1997).

22. Id. at 516 .

23. Id. at 519.

24. Id. "Congress does not enforce a constitutional right by changing what the right is. It has been given the power 'to enforce,' not the power to determine what constitutes a constitutional violation." Id. (quoting U.S. Const. Amend. XIV, §5).

25. Id. at 519-20. "RFRA is so out of proportion to a supposed remedial or preventive object that it cannot be understood as responsive to, or designed to prevent, unconstitutional behavior. It appears, instead, to attempt a substantive change in constitutional protections." Id. at 532. For a discussion of the Boerne test, see Evan H. Caminker, "Appropriate" Means-Ends Constraints on Section 5 Powers, 53 STAN. L. REV. 1127 (2001).

26. Pub. L. No. 103-141, 107 Stat. 1488 (1993) (codified at 42 U.S.C. $\$ 2000 b b-4)$ (ruled unconstitutional 1997).

27. Boerne, 521 U.S. at 517. Boerne stressed that "Legislation which deters or remedies constitutional violations can fall within the sweep of Congress' enforcement power even if in the process it prohibits conduct which is not itself unconstitutional and intrudes into 'legislative spheres of autonomy previously reserved to the States."' Id. at 518 (quoting Fitzpatrick v. Bitzer, 427 U.S. 445,455 (1976)).

28. Id. at 536 . 
"due regard"29 that were owed to congressional enactments. Boerne acknowledged that it has "been clear from the early days of the Republic" that "[w]hen Congress acts within its sphere of power and responsibilities, it has not just the right but the duty to make its own informed judgment on the meaning and force of the Constitution." 30

Boerne was thus "a transitional case," " because it both asserted a new form of control over Section 5 power and simultaneously accorded "due regard" to Congress's legislative judgment about the form and substance of that power. Boerne went out of its way to approve earlier relevant precedents, like City of Rome v. United States, ${ }^{32}$ Oregon v. Mitchell,,$^{33}$ South Carolina v. Katzenbach, ${ }^{34}$ and even aspects of Katzenbach v. Morgan, ${ }^{35}$ in which the Court had interpreted "the sweep of Congress's enforcement power" under the Reconstruction Amendments to extend considerably beyond the bounds of what a court might find to violate these Amendments. ${ }^{36}$

Garrett, like Boerne, restricts the scope of Section 5 power. It is explicitly concerned with protecting "the long-settled principle that it is the responsibility of this Court, not Congress, to define the substance of constitutional guarantees." ${ }^{37}$ Garrett erodes the distinction between legislative and judicial enforcement of Section 1 by adding a new two-part evidentiary requirement to Section 5 jurisprudence. ${ }^{38}$ First, Garrett requires that "the scope of the constitutional right at issue" be specified "with some precision." ${ }^{39}$ Second, Garrett requires that Congress adduce evidence that this right has been systematically violated. Garrett holds that Congress could have enacted Title I pursuant to Section 5 only if Congress had "identified a history and pattern of

29. Id. at 531 .

30. Id. at 535 .

31. William W. Buzbee \& Robert A. Schapiro, Legislative Record Review, 54 STAN. L. REV. $87,112(2001)$.

32. 446 U.S. $156(1980)$.

33. 400 U.S. 112 (1970).

34. 383 U.S. 301 (1966).

35. 384 U.S. 641 (1966).

36. Boerne, 521 U.S. at 518. Three years later, in Kimel v. Florida Board of Regents, 528 U.S. $62(2000)$, the Court deliberately stressed the notion that legislative and judicial enforcement of Section 1 could differ, holding that:

Congress' $\S 5$ power is not confined to the enactment of legislation that merely parrots the precise wording of the Fourteenth Amendment. Rather, Congress' power 'to enforce' the Amendment includes the authority both to remedy and to deter violation of rights guaranteed thereunder by prohibiting a somewhat broader swath of conduct, including that which is not itself forbidden by the Amendment's text.

Id. at 81 (citations omitted). Kimel used the concept of "reasonably prophylactic legislation," $i d$. at 88, which probably derived from Justice Powell's dissent in City of Rome v. United States, 446 U.S. 156, 202 (1980) (Powell, J., dissenting), to explain how the Court could retain exclusive control over constitutional meaning while at the same time authorize Congress to employ its Section 5 power to create rights which the Court was itself unwilling to enforce under Section 1.

37. Bd. of Trs. of Univ. of Ala. v. Garrett, 531 U.S. 356, 365 (2001).

38. But see infra note 41.

39. Garrett, 531 U.S. at 365. 
unconstitutional employment discrimination by the States against the disabled." ${ }^{, 40}$ This requirement must be satisfied before the congruence and proportionality test of Boerne can be applied.

Garrett interprets each stage of its test to mean that Congress must define constitutional rights and assemble evidence of their violation in virtually the same manner as would a court. The Garrett test thus imposes threshold conditions that sharply diminish the distinction between legislative and judicial enforcement of Section 1, which the Court so carefully preserved in both Katzenbach and Boerne. ${ }^{41}$ Garrett essentially requires that Congress act like a court before it has constitutional authority to act like a legislature. This misplaced requirement creates an unjustifiable impediment to the exercise of Section 5 power. Congress cannot, and should not, define rights, or prove their violation, in the same manner as would a court.

The difficulty is visible in the way that the Court applies the first stage of the Garrett test. Garrett views Title I of the ADA as a statute that enforces the right to equal protection of the law. But Garrett defines this right as the standard that a litigant would have to satisfy in order to prevail in a lawsuit alleging a violation of the Equal Protection Clause. Garrett observes that in constitutional litigation, classifications based upon disability are subject to rational basis review, which means that courts will find such classifications constitutional so long as "there is a rational relationship between the disparity of treatment and some legitimate governmental purpose."

40. Id. at 368 .

41. Garrett suggests, without elaborating, that Congress might enact prophylactic legislation of the sort discussed in Kimel once it has met these threshold evidentiary conditions. Garrett, 531 U.S. at 365 :

Congress is not limited to mere legislative repetition of this Court's constitutional jurisprudence. "Rather, Congress' power 'to enforce' the Amendment includes the authority both to remedy and to deter violation of rights guaranteed thereunder by prohibiting a somewhat broader swath of conduct, including that which is not itself forbidden by the Amendment's text."

quoting Kimel, 528 U.S. at 81.

42. Garrett, 531 U.S. at 367 . In articulating its understanding of rational basis review, the Court implies that classifications that can be justified by "some legitimate governmental purpose" are constitutional even if they are motivated by "negative attitudes" or other "biases." Id. The Court thus suggests that Section 5 power would have to be justified by more than a congressional finding of animus against the disabled; the power could only be sustained if Congress were to find that the disabled were treated with pervasive irrationality. Two Justices of Garrett's five member majority, however, appear to cast doubt on this suggestion. Justices Kennedy and $O$ 'Connor write separately to stress the gravity of any finding that

the States in their official capacities, the States as governmental entities, must be held in violation of the Constitution on the assumption that they embody the misconceived or malicious perceptions of some of their citizens. It is a most serious charge to say a State has engaged in a pattern or practice designed to deny its citizens the equal protection of the laws, particularly where the accusation is based not on hostility but instead on the failure to act or the omission to remedy. ... The failure of a State to revise policies now seen as incorrect under a new understanding of proper policy does not always constitute the purposeful and intentional action required to make out a violation of the Equal Protection Clause. ... If the States had been transgressing the Fourteenth Amendment by their mistreatment or lack of concern for those with impairments, one would have 
This definition of the right makes little sense when applied to Congress. Rational basis review has always been explained as "a paradigm of $j$ judicial restraint," 43 because it reflects the principle that courts should be "very reluctant . . . in our federal system and with our respect for the separation of powers, to closely scrutinize legislative choices." ${ }^{, 44}$ Rational basis review expresses the appropriate level of deference that unelected judges should display to the democratically informed judgments of a legislature, and it thus has no logical relevance to Congress itself. Garrett inappropriately transforms the definition of a right that a court should use in analyzing claims of disability discrimination under the Equal Protection Clause into a framework for analyzing the scope of Congress's power to enforce the Equal Protection Clause. ${ }^{45}$

The more or less unconscious conflation of the substance of Section 1 rights with the distinct institutional context of adjudication was vividly on display during the oral argument of Garrett, when the Court pressed plaintiffs' attorney Michael Gottesman concerning the nature of the constitutional violations which Congress sought to remedy by Title I:

MR. GOTTESMAN:... As the Government's brief shows, there was an enormous volume of State discrimination across wide sectors, really everywhere, which is not surprising if you accept the premise that there are pervasive, widely held prevalent views that stigmatize and disadvantage persons with disabilities.

QUESTION: Now, when you say discrimination in answer to this question, you mean-

MR. GOTTESMAN: Fourteenth Amendment-

QUESTION: - unconstitutional-

MR. GOTTESMAN: Correct.

QUESTION: Unconstitutional action.

MR. GOTTESMAN: Correct. Congress had two-three kinds of evidence. Number 1, it had individual incidents, and it had them in substantial number.

QUESTION: By people who were acting for the State?

expected to find in decisions of the courts of the States and also the courts of the United States extensive litigation and discussion of the constitutional violations.

This confirming judicial documentation does not exist.

Id. at 375-76 (Kennedy, J., concurring) (citation omitted). This passage suggests that Title I could have been enacted pursuant to Section 5 were Congress to have found "hostility" or "the purposeful or intentional action required to make out a violation of the Equal Protection Clause." Id. at 375; see also Romer v. Evans, 517 U.S. 620, 634 (1996) (Equal Protection Clause inhibits laws born out of animosity). Although Justices Kennedy and O'Connor may differ with the Chief Justice over the definition of the rights guaranteed by the Equal Protection Clause, they are nevertheless wholly in accord with the majority opinion that Section 5 power must be predicated upon violations of Section 1 that would be enforceable by courts.

43. FCC v. Beach Communications, Inc., 508 U.S. 307, 314 (1993) (emphasis added). For a discussion, see Post \& Siegel, supra note 15, at 462-63.

44. Cleburne v. Cleburne Living Center, Inc., 473 U.S. 432, 441 (1985). See Post \& Siegel, supra note 15 , at $459-67$.

45. See Garrett, 531 U.S. at 382-85 (Breyer, J., dissenting). 
MR. GOTTESMAN: Yes. I'll give you-here's a couple of examples. A woman crippled by arthritis is denied a job as a teacher in a university because they don't want the students to have to look at her. That is prejudice of a kind that would violate the Fourteenth Amendment.

QUESTION: What was the basis for that finding?

MR. GOTTESMAN: Testimony of the teacher.

QUESTION: Was there-of the teacher?

MR. GOTTESMAN: Yes.

QUESTION: Was there any testimony on the other side?

MR. GOTTESMAN: No, because the State-

QUESTION: Just hear one side and make a finding? ...

QUESTION: One witness who says, the reason I didn't get promoted was my arthritis, and Congress says State-unconstitutional state discrimination.

MR. GOTTESMAN: There are hundreds of these, Your Honor, not one, hundreds. But broader than that-if Your Honor wants, I'll give you some more. A microfilmer at the Kansas Department of Transportation is fired, and he is told, the reason you are being fired is that we have now discovered that you have epilepsy. He has throughout his tenure there been performing above the standards required for employment there. Now, Your Honor can say-

QUESTION: That is unconstitutional discrimination?

MR. GOTTESMAN: Yes.

QUESTION: That is irrational discrimination?

MR. GOTTESMAN: Yes.

QUESTION: Whether it's good or bad-

MR. GOTTESMAN: Yes.

QUESTION: -maybe it shouldn't exist, but you think there is no rational basis.

MR. GOTTESMAN: That is correct, and Congress thought that-

QUESTION: On the facts of this case, could the plaintiffs have gone to a court of competent jurisdiction and established an equal protection violation ${ }^{46}$

This exchange is fascinating. Gottesman offers examples of disabled persons being treated with "prejudice," arguing that such prejudice is unrelated to any legitimate governmental interest and hence in violation of the Equal Protection Clause of the Fourteenth Amendment. ${ }^{47}$ But the Court counters that, in the particular incidents cited

46. Transcript of Oral Argument at 35-37, Bd. of Trs. of Univ. of Ala. v. Garrett, 2000 WL 1523152 (U.S. October 11, 2000) (emphasis added) [hereinafter Garrett transcript].

47. "[I]f the constitutional conception of 'equal protection of the laws' means anything, it must at the very least mean that a bare ... desire to harm a politically unpopular group cannot constitute a legitimate governmental interest." United States Dep't of Agric. v. Moreno, 413 U.S. 528, 534 (1973). 
by Gottesman the state may nevertheless have had perfectly rational reasons for acting adversely to a disabled person. It queries how Congress could have ruled out the possibility of such reasons, because Congress had heard testimony from only one witness representing only "one side" to the alleged wrongdoing. Implicit throughout the Court's questioning is the yardstick of whether the plaintiff could "have gone to a court of competent jurisdiction and established an equal protection violation."

The fundamental difficulty of conceiving the relevant right in this way is that Congress cannot conduct minitrials, with full adversary hearings, as would "a court of competent jurisdiction." ${ }^{49}$ Congress does not possess the procedures or the time to delve into the circumstances of particular cases so as to characterize them in their full factual complexity. Instead Congress surveys the state of the nation by conducting hearings in order to make broad judgments about social trends and problems. ${ }^{50}$

In enacting the ADA, for example, Congress explicitly found that "the continuing existence of unfair and unnecessary discrimination and prejudice denies people with disabilities the opportunity to compete on an equal basis." 51 This finding is a generalization about how disabled persons are treated in this society. It is a generalization that, within the framework of legislative fact finding, seems to capture the essence of what the Court itself has several times announced is the thrust of the right to equal protection of the law, which is to secure "every person within the State's jurisdiction against intentional and arbitrary discrimination." 52 The Court has itself

48. Garrett transcript, supra note 46 , at *37.

49. Id. Yet the Court, when reviewing examples of discrimination against the disabled adduced in the legislative record, cannot resist remarking that " $[w]$ hether they were irrational under our decision in Cleburne is more debatable, particularly when the incident is described out of context." Garrett, 531 U.S. at 370 (emphasis added). The Court even implies that to reach a definitive conclusion "each incident" would have to be subject to a "fuller examination." $I d$. $C f$. Fullilove v. Klutznick, 448 U.S. 448, 506 (1980) (Powell, J., concurring) ("Although the discriminatory activities were not identified with the exactitude expected in judicial or administrative adjudication, it must be remembered that 'Congress may paint with a much broader brush than may this Court ....' Oregon v. Mitchell, 400 U.S. 112, 284 (1970)(Stewart, J., concurring in part and dissenting in part)").

50. On the contrast between legislative and judicial fact finding, see Garrett, 531 U.S. at 37980 (Breyer, J., dissenting) (" $[\mathrm{A}]$ legislature is not a court of law. And Congress, unlike courts, must, and does, routinely draw general conclusions.").

51. 42 U.S.C. $\S 12,101(a)(9)$. Congress also found that

individuals with disabilities are a discrete and insular minority who have been faced with restrictions and limitations, subjected to a history of purposeful unequal treatment, and relegated to a position of political powerlessness in our society, based on characteristics that are beyond the control of such individuals and resulting from stereotypic assumptions not truly indicative of the individual ability of such individuals to participate in, and contribute to, society.

Id. $\S 12,101(\mathrm{a})(7)$.

52. Vill. of Willowbrook v. Olech, 528 U.S. 562, 564 (2000) (quoting Sioux City Bridge Co. v. Dakota County, 260 U.S. 441,445 (1923)). Garrett announces that

States are not required by the Fourteenth Amendment to make special accommodations for the disabled, so long as their actions toward such individuals are rational. They could quite hardheadedly —and perhaps hardheartedly —hold to job-qualification requirements which do not make allowance for the disabled. If special accommodations for the disabled are to be required, they have to come 
instructed us that treatment "born of animosity toward the class of persons affected" violates this right. ${ }^{53}$ Yet Garrett disregards Congress's finding that prejudice pervasively harms disabled persons, because the finding is not in the form that a court would employ in holding that the Equal Protection right of a particular plaintiff has been violated.

Because the Court conceives constitutional rights from a judicial rather than a legislative standpoint, it applies the second stage of the Garrett test in a way that imposes impractical and dysfunctional evidentiary requirements on congressional lawmaking. ${ }^{54}$ The second stage of the Garrett test asks whether Congress has assembled evidence demonstrating that a constitutional right has been systematically violated; Garrett thus seeks to determine whether "Congress did in fact identify a pattern of irrational state discrimination in employment against the disabled." 55 At the outset we note that this evidentiary requirement represents a remarkable repudiation of the Court's position in Boerne. The Court in Boerne had observed that Congress's Section 5 power should not ordinarily be determined by a review of legislative history, because

judicial deference, in most cases, is based not on the state of the legislative record Congress compiles but 'on due regard for the decision of the body constitutionally appointed to decide.' As a general matter, it is for Congress to determine the method by which it will reach a decision. ${ }^{56}$

Garrett abandons any pretence to such deference. ${ }^{57}$ It holds that the existence of

from positive law and not through the Equal Protection Clause.

Garrett, 531 U.S. at 367-68. This passage confuses the simple failure to provide "special accommodations for the disabled" with the reasons for that failure. States may fail to "make allowance for the disabled" because of hardhearted economic calculations, or they may fail to make such allowances because of "prejudice." Congress found that such failures, as a general matter, were infected with "prejudice" and "purposeful unequal treatment." See supra note 51. At least six Justices would appear to conclude that such failures would implicate the right to equal protection of the law. See supra note 42.

53. Romer v. Evans, 517 U.S. 620, 634 (1996).

54. For a formidable critique of Garrett's evidentiary requirements on the ground that they misunderstand how legislatures function, see Philip P. Frickey \& Steven S. Smith, Judicial Review, the Congressional Process, and the Federalism Cases: An Interdisciplinary Critique, 111 YALE L. J. 1707 (2002).

55. Garrett, 531 U.S. at 368.

56. Boerne, 521 U.S. at 531-32 (citation omitted). See also Fullilove v. Klutznick, 448 U.S. 448,478 (1980) ("Congress, of course, may legislate without compiling the kind of 'record' appropriate with respect to judicial or administrative proceedings.") (Opinion of Burger, C.J.).

57. For an example of the contemporary Court exercising such deference in the context of the evidentiary requirements needed to support a state municipal ordinance restricting speech, see Renton v. Playtime Theatres, Inc., 475 U.S. 41, 50-52 (1986). Renton held that courts should exercise "deference" to such municipal "evidence": "[A] municipality may rely on any evidence that is 'reasonably believed to be relevant' for demonstrating a connection between speech and a substantial, independent government interest." City of Los Angeles v. Alameda Books, Inc., 122 S. Ct. 1728, 1729 (2002) (Plurality opinion of O'Connor, J.). The contrast between the evidentiary requirements of Renton and those of Garrett is striking. It is remarkable that the Court refuses to extend to Congress the same deference that it has been willing to 
Section 5 power depends entirely on "the evidence that Congress considered." The point of requiring "a close review of the relevant materials" ensure that congressional Section 5 power is exercised only in circumstances where there is a pattern of judicially cognizable violations of the Fourteenth Amendment.

This "judicialization" 60 of congressional lawmaking underlies Garrett's announcement of a new and startling rule that deems irrelevant much of the evidence that Congress had received in enacting Title I. Garrett prohibits Congress from exercising its Section 5 power to abrogate state sovereign immunity unless it first compiles evidence of irrational action by states, and Garrett defines "states" not in terms of the institutions subject to the requirements of Section 1 of the Fourteenth Amendment, but in terms of the institutions that can claim Eleventh Amendment immunity ${ }^{61}$ In a striking non sequitur, the Court argues that "[i]t would make no sense to consider constitutional violations" by "units of local government," because "only the States are the beneficiaries of the Eleventh Amendment."62 At issue in Garrett, however, is not the application of the Eleventh Amendment, but the constitutionality of Section 5 legislation. If units of local government are violating Section 1 of the Eleventh Amendment by irrationally discriminating against the disabled, Congress has power to enact Title I of the ADA under Section $5 .{ }^{63}$ Congress's authority under Section 5 is determined by the standards of the Fourteenth Amendment, and not by the Eleventh Amendment criteria Garrett employs. Congress's Section 5 power circumscribes Eleventh Amendment immunities, and not the reverse. ${ }^{64}$

extend to a municipality in the context of ordinances that arguably infringe First Amendment rights.

58. Garrett, 531 U.S. at 374. "The legislative record of the ADA, however, simply fails to show that Congress did in fact identify a pattern of irrational state discrimination in employment against the disabled." Id. at 368 . For powerful critiques of the concept of the "legislative record" presupposed by Garrett, see Buzbee \& Schapiro, supra note 31, at 91-97; Ruth Colker \& James J. Brudney, Dissing Congress, 100 MicH. L. Rev. 80, 115-23 (2001); Frickey \& Smith, supra note 54.

59. Garrett, 531 U.S. at 370.

60. Buzbee \& Schapiro, supra note 31, at 150.

61. Garrett, 531 U.S. at 368-69. Thus Garrett requires Congress to provide evidence of a pattern of discrimination "by the States themselves," which would not include evidence of discrimination by "units of local governments, such as cities and counties," which do not receive Eleventh Amendment immunity. Id. at 368.

62. Id. at 369.

63. The bizarre quality of the Court's reasoning has led one circuit court to conclude that a determination that a statute is not a valid abrogation of Eleventh Amendment immunity does not necessarily mean that the statute is not a valid exercise of Congress' power to enforce the Fourteenth Amendment. Because the Fourteenth Amendment applies to local government entities not entitled to Eleventh Amendment immunity, the analysis of whether Congress has the power to enact legislation requires inquiry into constitutional violations by these entities in addition to entities entitled to Eleventh Amendment immunity.

Thompson v. Colorado, 258 F.3d 1241, 1253 n.7 (10th Cir. 2001). See Reickenbacker v. Foster, 274 F.3d 974, 982 n.60 (5th Cir. 2001).

64.

[W]e think that the Eleventh Amendment, and the principle of state sovereignty 
The Court's mistake is so egregious as to require an explanation. No doubt the Court was motivated by an intense desire to insulate states from federal regulation. But what lends Garrett's logic its cloak of plausibility is the implicit evocation of a judicial paradigm of evidentiary relevance. Garrett reasons about Section 5 legislation as if it were an accusation, and as if states subject to its regulation were defendants in a lawsuit. Justice Kennedy makes this analogy explicit in his concurring opinion, noting that "[i]t is a most serious charge to say a State has engaged in a pattern or practice designed to deny its citizens the equal protection of the laws. ..."65 Garrett's refusal to consider discrimination by local governments as relevant evidence of discrimination by state governments draws credibility from the principle that defendants "charged" in a court of law should be convicted based upon evidence of their own misbehavior, not upon evidence of the misconduct of others.

It is fundamentally misguided, however, to imagine that Section 5 legislation accuses states as though they were defendants in a lawsuit. Courts retrospectively assign blame and impose punishment on individual parties. Courts therefore exclude evidence that might tend to encourage judgments of guilt on the basis of improper inferences concerning propensity or association. But when Congress exercises its Section 5 power, it is not acting to "charge" or accuse particular states. If Congress finds that there is a constitutional problem worthy of legislative remedy, no particular state is stigmatized as if it were a defendant in a legal action.

There is therefore no reason to confine Congress to the artificially stringent rules of evidentiary relevance that would be appropriate for a court making judgments about individual liability. ${ }^{66}$ If Congress finds that prejudice is pervasively present in the treatment of the disabled by official institutions subject to Section 1 of the Fourteenth Amendment, Congress ought to be able to infer that prejudice is also pervasive in the treatment of the disabled by state institutions possessing Eleventh Amendment immunity. This inference would be acceptable to any rational policymaker, and for this reason it ought also to be sufficient to sustain the enactment of Section 5 legislation. ${ }^{67}$

which it embodies are necessarily limited by the enforcement provisions of $\S 5$ of the Fourteenth Amendment. In that section Congress is expressly granted authority to enforce "by appropriate legislation" the substantive provisions of the Fourteenth Amendment, which themselves embody significant limitations on state authority. When Congress acts pursuant to $\S 5$, not only is it exercising legislative authority that is plenary within the terms of the constitutional grant, it is exercising that authority under one section of a constitutional Amendment whose other sections by their own terms embody limitations on state authority. We think that Congress may, in determining what is "appropriate legislation" for the purpose of enforcing the provisions of the Fourteenth Amendment, provide for private suits against States or state officials which are constitutionally impermissible in other contexts. Fitzpatrick v. Bitzer, 427 U.S. 445, 456 (1976) (Rehnquist, J.) (citations omitted).

65. Garrett, 531 U.S. at 375 (Kennedy, J., concurring). Kennedy continues: "[s]tates can, and do, stand apart from the citizenry. States act as neutral entities, ready to take instruction and to enact laws when their citizens so demand." Id.

66. Cf. South Carolina v. Katzenbach, 383 U.S. at 330 (1966) ("Congress is clearly not bound by the rules relating to statutory presumptions in criminal cases when it prescribes civil remedies against other organs of government under $\S 2$ of the Fifteenth Amendment.").

67. See, e.g., Turner Broadcasting System, Inc. v. FCC, 520 U.S. 180, 195 (1997) ("In reviewing the constitutionality of a statute, 'courts must accord substantial deference to the 
Not only does Garrett prohibit Congress from drawing reasonable inferences from an important category of evidence, presumably on the ground that such evidence would be inadmissible in lawsuits charging states possessing Eleventh Amendment immunity with violating the Fourteenth Amendment, but Garrett also reviews the evidence assembled by Congress that might potentially have been admissible in such lawsuits, and it concludes that this evidence is insufficient to justify the exercise of Section 5 power. According to Garrett, the evidence of constitutional violations before Congress consisted only of "half a dozen examples" of irrational discrimination against disabled persons. ${ }^{68}$ Garrett holds that

\begin{abstract}
even if it were to be determined that each incident upon fuller examination showed unconstitutional action on the part of the State, these incidents taken together fall far short of even suggesting the pattern of unconstitutional discrimination on which $\S 5$ legislation must be based. ... It is telling, we think, that ... Congress assembled only such minimal evidence of unconstitutional state discrimination in employment against the disabled. ${ }^{69}$
\end{abstract}

What we find most "telling" about this holding, however, is the implicit assumption that Congress can exercise its Section 5 power only on the basis of the same kind of concrete and specific evidence of illegal conduct that a court is required to assemble in reaching a judgment about the liability of parties. If a court wishes to issue a broad remedy, like a structural injunction, it must aggregate incidents of illegal conduct to justify the conclusion that there is a pattern or practice of such illegal behavior. Because courts allocate blame and punishment, they are careful not to impose remedies without evidence of particular wrongdoing, whether in the singular or in the aggregate. Garrett applies the second stage of its test to prohibit Congress from enacting Section 5 legislation unless it also can aggregate specific examples of wrongdoing.

The kind of evidence the Court requires Congress to gather before exercising its Section 5 power reflects a misunderstanding of the function of legislation. Congress enacts Section 5 legislation in order to vindicate public understandings about the nation's needs and obligations under the Fourteenth Amendment, not to single out wrongdoers for blame or punishment. In determining whether there are recurring social interactions that warrant legislation that would enforce the provisions of the Amendment, Congress can consult evidence of a sort that could not support judicial findings that individual defendants have violated the Constitution. ${ }^{70}$ Garrett simply ignores these legislative forms of evidence. ${ }^{71}$ So, for example, Garrett does not stop to

predictive judgments of Congress.' ... Our sole obligation is 'to assure that, in formulating its judgments, Congress has drawn reasonable inferences based on substantial evidence."') (citations omitted).

68. Garrett, 531 U.S. at 369.

69. Id. at 370 (citations omitted).

70. Cf. South Carolina v. Katzenbach, 383 U.S. 301,330 (1966) ("In identifying past evils, Congress obviously may avail itself of information from any probative source. See Heart of Atlanta Motel v. United States, 379 U.S. 241, 252-53; Katzenbach v. McClung, 379 U.S. at 299301.").

71. For a good overview of the extensive evidence before Congress, see Brief of Amicus Curiae of the National Council on Disability in Support of Respondents, Board of Trustees of the University of Alabama v. Garrett, 531 U.S. 356 (2001)(No.99-1240). Congress had before 
consider the historical evidence supporting Congress's finding that "historically, society has tended to isolate and segregate individuals with disabilities"; ${ }^{72}$ or the sociological evidence supporting Congress's finding that disabled persons suffer from negative "stereotypic assumptions"; ${ }^{73}$ or the psychological evidence supporting Congress's finding that disabled persons suffer from "prejudice." 74

Garrett's notion of pertinent evidence excludes sub silentio the most common forms of congressional fact finding. It does so on the unstated premise that judicially cognizable forms of evidence are prerequisite for the exercise of Section 5 power. Yet the Court would not require Congress in the exercise of its commerce power to adopt such juricentric rules of evidence. Congress can ban asbestos or margarine from interstate commerce without first compiling a record that consists of an aggregation of discrete instances of wrongdoing or harm.

One reason that Congress is not generally subject to a requirement analogous to the second stage of the Garrett test is because congressional fact finding varies in important respects from judicial fact finding. It is essential that judicial fact finding be impartial and disinterested. When looking for guidance in policymaking, Congress may hold hearings in which partisan conflict sharpens legislative fact finding in ways roughly similar to the adversary system, but the analogy is at best imperfect. Congress commonly holds hearings to generate and consolidate the political will to respond to public problems and conflicts. ${ }^{75}$ Legislative hearings educate the nation and summon it

it, among other evidence, a 1983 publication of the U.S. COMM'N ON CIVIL RIGHTS, ACCOMMODATING THE SPECTRUM OF INDIVIDUAL ABILITIES (1993) [hereinafter ACCOMMODATING], and a 1989 publication of the ADVISORY COMM'N ON INTERGOVERNMENTAL Relations, Disability Rights Mandates: Federal and State Compliance with Employment Protections and ARchitectural Barrier Removal (A-111, April 1989) [hereinafter DiSABILITY RightS MANDATES].

72. 42 U.S.C. $\S 12,101(\mathrm{a})(2)$. See also Olmstead v. Zimring, 527 U.S. 581, 608 (1999) (Kennedy, J., concurring) ("persons with mental disabilities have been subject to historic mistreatment, indifference, and hostility."); H.R. REP. No. 101-485 pt. 2, at 2, 87-88 and pt. 3, at 45-46 (1990) reprinted in 1990 U.S.C.C.A.N. 267, 369-71, 468-69; ACCOMMODATING, supra note 71 , at $17-22$.

73. 42 U.S.C. $\S 12,101(\mathrm{a})(7)$. See City of Cleburne v. Cleburne Living Center, 473 U.S. 432, 461-64 (1985) (Marshall, J., dissenting) ("[L] engthy and continuing isolation of the retarded has perpetuated the ignorance, irrational fears, and stereotyping that long have plagued them."); H.R. REP. No. 101-485 pt. 2, at 5, 50-51 and pt. 3, pp. 45, 50 (1990) reprinted in 1990 U.S.C.C.A.N. 267, 332-33, 468, 473; ACCOMMODATING, supra note 71, at 25.

74. 42 U.S.C. at $\S 12,101(\mathrm{a})(9)$. See, e.g., School Board of Nassau Cty. v. Arline, 480 U.S. $273,278 \mathrm{n} .2$ (1987) (citing "evidence that 'negative attitudes and practices toward the disabled resemble those commonly attached to 'underprivileged ethnic and religious minority groups."'); Id. at $285 \mathrm{n} .13$ (citing legislative history of $\S 504$ of the Rehabilitation Act of 1973); Alexander v. Choate, 469 U.S. 287,295 n.12 (1985) ("[t]o be sure, well-cataloged instances of invidious discrimination against the handicapped do exist. Wegner, The Antidiscrimination Model Reconsidered: Ensuring Equal Opportunity Without Respect to Handicap Under Section 504 of the Rehabilitation Act of 1973, 69 CORNELL L. REV. 401, 403, n. 2 (1984)."); HOUSE REP. No. 101-485 pt. 2, at 55 (1990); DisABILITY RIGHTS MANDATES, supra note 71, at 72-73; ACCOMMODATING, supra note 71, at 22-27.

75. On the "political accountability" of legislative fact finding, see Colker \& Brudney, supra note 58 , at $119-20$. 
to action; they have political functions that are without judicial analogy. These functions would be undermined were Congress required to transform legislative hearings into disinterested judicial inquiries, much less into trials that issue indictments.

That is why the juridical model underlying the second stage of the Garrett test, which seems to require Congress to assemble evidence that might be used to convict states of violations of the Fourteenth Amendment, is fundamentally misplaced. States charged like prisoners in the dock would be unlikely to welcome the ADA or to participate willingly and wholeheartedly in its enforcement. ${ }^{76}$ Legislative hearings ought not to stimulate adversaries; their primary purpose is to inspire new forms of collective commitment. Even if a prerequisite of Section 5 power is a pattern of constitutional violations, the evidence necessary to establish such a pattern should not be the same as the evidence necessary to expose institutions to the serious threat of litigation. Any such requirement would only deter the forms of voluntary and collective action required for legislative enforcement of constitutional rights. ${ }^{77}$

The evidentiary requirements imposed by Garrett are anomalous. They are hostile to ordinary forms of congressional fact finding, dismissive of the evidence Congress in fact gathered, and quick to demand new, resource-intensive, and counterproductive forms of inquiry. It is exceedingly unusual for the Court to impose such requirements upon Congress, as Justice Powell noted in his concurring opinion in Fullilove v. Klutznick, ${ }^{78}$ which flatly rejected the contention that a Section 5 statute was unconstitutional because its "legislative history" failed to contain adequate "congressional findings of statutory or constitutional violations":

Congress is not an adjudicatory body called upon to resolve specific disputes between competing adversaries. Its constitutional role is to be representative rather than impartial, to make policy rather than to apply settled principles of law. The petitioners' contention that this Court should treat the debates on $\S 103(\mathrm{f})(2)$ as the complete "record" of congressional decisionmaking underlying that statute is essentially a plea that we treat Congress as if it were a lower federal court. But Congress is not expected to act as though it were duty bound to find facts and make conclusions of law. The creation of national rules for the governance of our society simply does not entail the same concept of recordmaking that is appropriate to a judicial or administrative proceeding. Congress has no

76. See Buzbee \& Schapiro, supra note 31 , at 156.

77. Cf. Wygant v. Jackson Board of Education, 476 U.S. 267, 290-91 (1986) (O'Connor, J., concurring in part):

The imposition of a requirement that public employers make findings that they have engaged in illegal discrimination before they engage in affirmative action programs would severely undermine public employers' incentive to meet voluntarily their civil rights obligations. This result would clearly be at odds with this Court's and Congress' consistent emphasis on "the value of voluntary efforts to further the objectives of the law." Such results cannot, in my view, be justified by reference to the incremental value a contemporaneous findings requirement would have as an evidentiary safeguard.

(quoting Regents of Univ. of Calif. v. Bakke, 438 U.S. 265, 364 (1978) (opinion of Brennan, White, Marshall, and Blackmun, JJ.) (citations omitted)).

78. 448 U.S. 448 (1980). 
responsibility to confine its vision to the facts and evidence adduced by particular parties. Instead, its special attribute as a legislative body lies in its broader mission to investigate and consider all facts and opinions that may be relevant to the resolution of an issue. . . . Acceptance of petitioner's argument would force Congress to make specific factual findings within respect to each legislative action. Such a requirement would mark an unprecedented imposition of adjudicatory procedures upon a co-ordinate branch of Government. Neither the Constitution nor our democratic tradition warrants such a constraint on the legislative process. ${ }^{79}$

Why then does Garrett impose such atypically stringent restrictions on the constitutional deliberations of a co-ordinate branch of government? We suggest that it is in large measure because the Court perceives Congress's exercise of Section 5 power as potentially endangering the Court's prerogative to declare constitutional meaning. When Congress enacts legislation designed to "enforce" the provisions of Section 1 of the Fourteenth Amendment, and when this legislation is predicated on institutional perspectives that differ from the Court's own practices, the Court fears that Congress may be interpreting Section 1 in a way that differs from the Court's precedents. The Court appears to find the possibility of such interpretation intolerable. Garrett thus frames its evidentiary requirements in terms of the need to prevent Congress from rewriting "the Fourteenth Amendment law laid down by this Court in Cleburne." 80

The ultimate reductio of this approach is that Congress can legislate pursuant to Section 5 only to remedy violations that courts have already condemned. Justice Kennedy, at least, may have indicated some willingness to embrace this reductio as the logical terminus of Garrett's reasoning. In a concurring opinion joined by Justice O'Connor, Kennedy writes that:

If the States had been transgressing the Fourteenth Amendment by their mistreatment or lack of concern for those with impairments, one would have expected to find in decisions of the courts of the States and also the courts of the United States extensive litigation and discussion of the constitutional violations. This confirming judicial documentation does not exist. ${ }^{81}$

Garrett thus brings us face-to-face with what we may call the "juricentric Constitution," the notion that courts have the exclusive prerogative to declare constitutional meaning. The juricentric Constitution does not follow from the Court's holding in Marbury v. Madison. ${ }^{82}$ In Marbury, Chief Justice Marshall reasoned that because federal courts must decide cases according to law, and because the Constitution is a form of law, federal courts must declare the Constitution's meaning in the context of deciding particular cases. We do not question this logic. We observe

79. Id. at 502-03.

80. Garrett, 531 U.S. at 374 (Kennedy, J., concurring opinion).

81. Id. at 375-76.

82. 5 U.S. (1 Cranch) 137 (1803). 
only that it does not sustain Garrett's vision of the juricentric Constitution, which holds that courts, and only courts, have the right to interpret the Constitution.

Garrett exemplifies, but does not defend, the juricentric Constitution. The closest we possess to an explanation of this view is a passage from Boerne, which initiated the contemporary Court's assault on congressional Section 5 power:

If Congress could define its own powers by altering the Fourteenth Amendment's meaning, no longer would the Constitution be "superior paramount law, unchangeable by ordinary means." It would be "on a level with ordinary legislative acts, and, like other acts, . . alterable when the legislature shall please to alter it." Marbury v. Madison, 1 Cranch, at 177, 2 L.Ed. 60. Under this approach, it is difficult to conceive of a principle that would limit congressional power. Shifting legislative majorities could change the Constitution and effectively circumvent the difficult and detailed amendment process contained in Article $V^{83}$

The passage depicts the Constitution as having a fixed and "paramount" meaning that persists in history. "[O]rdinary" law is "alterable," but the Constitution stands "unchangeable." This image is comforting in its familiarity. The notion that the Constitution was written "to endure for all times" ${ }^{84}$ is certainly a common trope for expressing our understanding of the Constitution as fundamental law. But Boerne gives this familiar understanding of the Constitution a new edge, mobilizing it as a reason for attacking Section 5 legislation when such legislation deviates from standards that a court would use to enforce Section 1 of the Fourteenth Amendment.

Boerne suggests that Congress, by reason of its institutional differences from the Court, lacks the integrity needed to speak for a Constitution that must endure as fundamental and enduring law. Unless carefully monitored by a court, "[s]hifting legislative majorities [will] change the Constitution and effectively circumvent the difficult and detailed amendment process contained in Article V." Congress will

83. Boerne, 521 U.S. at 529 . We note, parenthetically, that this passage assumes that the Fourteenth Amendment has a singular and universal meaning, although the Court has itself suggested more than once that the significance of constitutional provisions might vary depending upon whether they are enforced by courts or by the Congress. See, e.g., Garrett, 531 U.S. at 38385 (Breyer, J., dissenting); Palmer v. Thompson, 403 U.S. 217, 227 (1971); Griffin v. Brekenridge, 403 U.S. 88 (1971); Jones v. Alfred H. Mayer Co., 392 U.S. 409 (1968); United States v. Nelson, 277 F.3d 164 (2d Cir. 2002); Lawrence G. Sager, Fair Measure: The Legal Status of Underenforced Constitutional Norms, 91 HARV. L. REV. 1212 (1978). As Garrett so vividly illustrates, this assumption of invariant meaning is a major conceptual underpinning of the juricentric Constitution. It was persuasively attacked by Justice Breyer in his dissent in Garrett, when he reasoned that the Court's appeal to rational basis review essentially applied "a rule designed to restrict courts as if it restricted Congress' legislative power," and when he observed that there was "simply no reason to require Congress . . . to adopt rules or presumptions that reflect a court's institutional limitations." Garrett, 531 U.S. at 384-85 (Breyer, J., dissenting). We have discussed the assumption of singular Constitutional meaning elsewhere, however, and we will not repeat ourselves here. Post \& Siegel, supra note 15, at 462-73, 495-96.

84. W. Va. State Bd. of Educ. v. Barnette, 319 U.S. 624, 665 (1943) (Frankfurter, J., dissenting). See McCulloch v. Maryland, 17 U.S. (4 Wheat.) 316, 407, 415 (1819). 
violate the Constitution as "superior paramount law, unchangeable by ordinary means" and reduce it to "ordinary legislative acts ... alterable when the legislature shall please to alter it."

Although the Court has elsewhere observed that Congress and the Court might enforce the Constitution differently for wholly benign reasons, as for example, because legislatures and courts possess distinct institutional structures and resources as well as distinct forms of democratic legitimacy, ${ }^{85}$ Boerne imagines the distinction between legislative and adjudicative enforcement as the potential site of corruption or infidelity. This is because Boerne imagines the Constitution as the kind of law that courts respect, but that legislatures often violate. Legislatures, as Boerne understands them, are political bodies constituted to satisfy preferences without regard for principle. As such, they lack the institutional discipline and commitment necessary to respect the Constitution. If allowed to legislate about constitutional matters without strict judicial oversight, Congress will degrade and contaminate the Constitution with politics. Only courts possess the institutional competence and integrity to proclaim the stable legal understandings that comprise the Constitution as "superior, paramount law."

Boerne thus justifies strict review of Section 5 legislation upon the basis of a particular understanding of the relationship between law and politics in the American constitutional tradition. Because it assumes that law consists of principles that must be insulated from the ordinary tug and haul of politics, and because it understands the Constitution as a form of fundamental law, Boerne concludes that courts must protect the Constitution from the corruption of politics. Courts, in other words, must protect the Constitution from the people.

Although this is a common way of conceiving the relationship between law and politics in the American constitutional tradition, it is certainly not the only way. Woodrow Wilson, for example, appealed to an equally entrenched but radically different understanding when he claimed that "the Constitution of the United States is not a mere lawyers' document: it is a vehicle of life, and its spirit is always the spirit of the age. ${ }^{\prime 86}$ Wilson summons a vision of the Constitution that is proudly political. He invokes the Constitution as the moving spirit of the nation's deepest ideals and values. The Constitution is what "We the People" have collectively made and what we aspire to make in the future. Because it symbolizes "our whole experience" as "a nation," ,87 the Constitution reflects the highest forms of collective life that we can achieve through politics. ${ }^{88}$ Wilson thus reverses the valence of the law/politics distinction. He represents politics as primary and generative, while depicting law as derivative and potentially repressive. Legal reason can suffocate the Constitution if it fails to grasp the social understandings vital to the formulation and application of constitutional ideals.

This view of the relationship between law and politics is at least as familiar as the juricentric imagery advanced in Boerne. It is striking that the two perspectives are almost diametrically opposed. The juricentric Constitution of Boerne imagines law as

85. See supra note 83.

86. WOODROW WILSON, CONSTITUTIONAL GOVERNMENT IN THE UNITED STATES 69 (1908).

87. Missouri v. Holland, 252 U.S. 416, 433 (1920).

88. "For us," said Franklin Roosevelt, "the Constitution is a common bond." The Constitution of the United States Was a Layman's Document, Not a Lawyer's Contract (Sept. 17, 1937) in 6 The Public Papers and Addresses of Franklin D. Roosevelt 359, 367 (Samuel I. Rosenman ed., 1941) [hereinafter PUB. PAPERs]. 
firm and enduring, and it condemns politics as labile and fickle, perennially threatening to violate the principles of legal reason. The Constitution described by Wilson, in contrast, imagines politics as a constructive medium of democratic selfdetermination, and it consigns law to the domain of deracinated and technical reason, perennially threatening to throttle the vital impulses of democratic self-government. It is remarkable that our constitutional traditions should contain with apparently equal conviction two such opposite images of the relationship between law and politics.

The tension between these two images suggests the volatility of the law/politics distinction in our constitutional culture. We are capable of prizing law by denigrating politics, or of prizing politics by denigrating law, but we rarely imagine law and politics as respectfully coexisting, as they often do. In fact, when we privilege law over politics, or politics over law, we are testifying to the primacy of different values that give defining shape to our constitutional tradition.

When we prize law over politics, we signify our dedication to the Constitution as embodying the rule of law, which encompasses and sustains our conception of individual rights and liberties. Our commitment to the rule of law requires courts to impose constitutional limits on majoritarian politics so as to preserve the very values on which democratic life is premised ${ }^{89}$ But when we prize politics over law, we celebrate the Constitution as the framework of our self-governance. We do not imagine the Constitution as a limit on democratic will, but instead as its deepest expression. ${ }^{90}$ We signify our belief, as Franklin Roosevelt emphasized, that "the flag and the Constitution ... stand for democracy not tyranny; for freedom, not subjection."

Although there are surely significant tensions between the rule of law and democratic self-determination, ${ }^{92}$ it is clear that each is an indispensable element of our constitutional tradition. The ideals are in fact deeply interdependent. The value of selfdetermination requires the rule of law so that popular will does not slide into fascism and so that politics remains true to the values that animate democracy itself. ${ }^{93}$ The value of the rule of law, on the other hand, must be responsive to political selfdetermination if it is to retain legitimacy in a democratic state. That is why we have decreed that our judges are to be nominated and approved by the representative branches of government, rather than serving as a technically expert, self-perpetuating elite. Charles Black would sometimes ask his students why Lincoln did not respond to the South's secession by petitioning the Supreme Court for an injunction against the South's blatantly illegal conduct. The point of the question was to encourage an appreciation of how the rule of law implicitly depends upon antecedent political

89. As Andrew Jackson once wrote to his nephew", "all the rights secured to the citizens under the constitution [are] worth nothing, and a mere buble [sic], except guaranteed to them by an independent and virtuous Judiciary." Letter from Andrew Jackson to Andrew Jackson Donelson, (July 5, 1822) in 3 CORRESPONDENCE OF ANDREW JACKSON, 1820-1828 at 167 (John Spencer Bassett ed.) (1928).

90. See Stephen Breyer, Our Democratic Constitution, 77 N.Y.U. L. REV. 245 (2002).

91. Franklin D. Roosevelt, We Are Fighting to Save a Great and Precious Form of Government for Ourselves and World, 5 PUB. PAPERs 230, 234 (June 27, 1936).

92. For a deep exploration of these tensions, see Frank I. MichelmaN, BRENNAN AND DEMOCRACY (1999).

93. See Frank 1. Michelman, Brennan and Democracy, 86 CALIF. L. REV. 399 (1998); Robert C. Post, Democracy, Popular Sovereignty, and Judicial Review, 86 CALIF. L. REV. 429 (1998). 
commitments and understandings.

If self-determination and the rule of law are each necessary, and if they each require the other, it would seem to follow that we ought not to pursue either in such a way as to incapacitate the other. This principle certainly underlies the deep resistance the political branches of government encounter whenever they act in ways that seem to threaten the rule of law. ${ }^{94}$ An example of this resistance is the Court's strong decision in Dickerson v. United States, ${ }^{95}$ which rebuffed Congress's effort to force the Court to apply a statute which, in the Court's view, offered an inadequate "substitute" 96 for judicially crafted protections necessary to safeguard a constitutional right. Political attempts to undermine the Court's judicial interpretation and application of constitutional rights typically arouse such suspicion, even where, as in the case of Boerne, there is disagreement about whether congressional legislation actually poses such a symbolic threat. ${ }^{97}$

94. See, e.g., Daniel O. Conkle, The Religious Freedom Restoration Act: The Constitutional Significance of an Unconstitutional Statute, 56 MONT. L. REV. 39, 53 (1995):

Congressional exercise of a substantive power of constitutional interpretation does not necessarily undermine the Supreme Court's primary interpretive function. Rather, the question is whether any particular exercise of that power significantly frustrates the Court's role. The question is one of degree. . . Much more problematic is congressional action that purports to reject the Court's basic standards or that otherwise works to impair the Court's constitutional function.

95. 530 U.S. 428 (2000). For discussions of Dickerson, see Michael C. Dorf \& Barry Friedman, Shared Constitutional Interpretation, 2000 SUP. Cr. Rev. 61; David A. Strauss, Miranda, the Constitution, and Congress, 99 MiCH. L. REv. 958 (2001).

96. Dickerson, 530 U.S. at 442.

97. Boerne was unique because "[c]ommon sense" suggested that RFRA was a direct "congressional effort to overrule the Supreme Court on a point of constitutional interpretation." Christopher L. Eisgruber \& Lawrence G. Sager, Why the Religious Freedom Restoration Act Is Unconstitutional, 69 N.Y.U. L. REv. 437, 469 (1994). "That is what RFRA's supporters wanted, and that is what they got." Id. at 473. See Neal Devins, Congressional Factfinding and the Scope of Judicial Review: A Preliminary Analysis, 50 DUKE L.J. 1169, 1196-97 (2001):

Congress's consideration of the RFRA focused exclusively on protesting the wrongness of Employment Division, Department of Human Resources of Oregon $v$. Smith, a 1990 Supreme Court interpretation of the Free Exercise Clause. Congressional hearings showcased witnesses from religious and other interest groups, nearly all of whom attacked Smith and calling upon the Justices to reverse it. In the end, with virtually no interest group opposition to the measure, Congress gave short-shrift to fact-finding in order to do precisely what RFRA's interest group sponsors asked for, that is, repudiate Smith.

Because RFRA sought to enforce the Free Exercise Clause by means of a standard that the Court had recently and explicitly rejected, many understood RFRA as a thumb in the eye of an independent judiciary. They understood RFRA to pose a majoritarian threat to the value of the rule of the law. This may account for the fact that whereas Kimel v. Florida Board of Regents, 528 U.S. 62 (2000), was five to four, as were United States v. Morrison, 529 U.S. 598 (2000), Garrett, 531 U.S. 356 (2001), and Florida Prepaid Postsecondary Education Expense Boardv. College Savings Bank, 527 U.S. 627 (1999), Boerne, by contrast, featured not a single dissent from the Section 5 analysis of the Court's opinion. Boerne was authored by Justice Kennedy, and in its relevant parts joined by Chief Justice Rehnquist and Justices Stevens, Scalia, Thomas, and Ginsburg. Justice O'Connor dissented from the Court's judgment on the ground that the 
The juricentric Constitution of Garrett represents the opposite danger from Dickerson. By insisting that Congress can exercise its Section 5 power only if it comports itself like a court, Garrett vindicates the value of the rule of law in ways that threaten the value of self-determination. Although constitutional theory is quick to apprehend and theorize the circumstances in which politics depends upon the rule of law, it is much slower to recognize the many ways in which the rule of law is itself dependent upon forms of democratic self-governance.

The root of this asymmetry is the instinctive conviction that we best secure the rule of law by insulating legal decisionmaking from political influence. This conviction is manifest in the passage from Boerne that we just analyzed. ${ }^{98}$ The Court depicts Article $\mathrm{V}$ as the single legitimate point of contact between the legal Constitution and the value of self-governance. The Court describes the Constitution as responsive to political culture only during those rare moments when "the difficult and detailed amendment process contained in Article $\mathrm{V} " 99$ is mobilized to authorize changes in the Constitution's text. On this view, the arduous procedures of Article V serve two distinct functions. They allow the Constitution to become responsive to political will, and they simultaneously protect the legal explication of the Constitution from the contamination of everyday politics.

This account of Article V captures certain truths about our constitutional tradition. The authority of the Constitution does in part derive from its democratic ratification, and we do expect the Court to interpret the ratified Constitution as a form of law that is not reducible to simple politics. ${ }^{100}$ Finley Peter Dunne notwithstanding, the decisions of "th' supreme coort" do not merely follow "th' iliction returns," 101 nor should they. The authority of the Court depends upon its claim to declare law, and that authority could not long persist were the Court continuously to issue opinions that participants in the legal profession or members of the public did not accept as within the margins of the "legal." Justices thus regard "a decision without principled justification" as "no judicial act at all." 102

Court had misinterpreted the Free Exercise Clause, but she specifically stated that "if I agreed with the Court's [free exercise] standard in Smith, I would join the opinion" and conclude that Congress lacked power under Section 5 to enact RFRA. Boerne, 521 U.S. at 545 (O'Connor, J., dissenting). Justice Souter dissented on the ground that the constitutionality of RFRA could not be decided without a full reconsideration of the Court's free exercise jurisprudence. Id. at 565-66 (Souter, J., dissenting). Justice Breyer joined the parts of O'Connor's dissenting opinion that addressed the interpretation of the Free Exercise Clause, but explicitly refused to reach the question of Section 5 power. Id. at 566 (Breyer, J., dissenting). Of course it is also relevant to the relative unanimity of Boerne that the case could be understood as setting forth a conception of Congress's Section 5 power that, when compared to Garrett, was relatively generous. See supra text accompanying notes $26-36$.

98. See supra text accompanying note 83.

99. Boerne, 521 U.S. at 529.

100. Because law "is a 'relatively autonomous' cultural form," competent judicial decisions are always mediated by the internal demands and norms of legal practice. Robert C. Post, Introduction to LAW AND THE ORDER OF CULTURE viii (Robert C. Post ed., 1991) (quoting Robert W. Gordon, Critical Legal Histories, 36 STAN. L. REv. 57, 101 (1984)).

101. Finley Peter DunNe, Mr. Dooley's Opinions 26 (New York, Harper Bros. 1906).

102. Planned Parenthood of Southeastern Pa. v. Casey, 505 U.S. 833, 865 (1992). See Henry P. Monaghan, Taking Supreme Court Opinions Seriously, 39 MD. L. Rev. 1, 19 (1979). 
But if it is true that courts properly struggle to distinguish constitutional interpretation from everyday politics, it does not follow that the practice of constitutional interpretation can or should be divorced from the political culture of the nation. To the contrary, the evolving political understandings of the nation shape constitutional law through many pathways outside the formal procedures of Article $\mathrm{V},{ }^{103}$ and this has significant normative consequences for the Court's practice of constitutional interpretation.

Seen from the external standpoint of history or political science, the Constitution is a cultural artifact firmly anchored in the political perspectives of its time. Legal historians find that constitutional interpretation evolves to reflect changes in American political culture. ${ }^{104}$ Political scientists find that Justices interpret the Constitution to advance perfectly ordinary political agendas. ${ }^{105}$ Indeed, the very Justices who were nominated by Republican Presidents elected on states' rights platforms ${ }^{106}$ are those

103. For a powerful historical demonstration of this point, see BRUCE ACKERMAN, WE THE PeOPle: Foundations (1991); BruCE ACKerman, We the PEOPle: Transformations (1998). See also Jack M. Balkin \& Sanford Levinson, Understanding the Constitutional Revolution, 87 VA. L. REV. 1045 (2001); Reva B. Siegel, Text in Contest: Gender and the Constitution from a Social Movement Perspective, 150 U. PA. L. REv. 297 (1997).

104.

[T] he theory that the Constitution is a written document is a legal fiction. The idea that it can be understood by a study of its language and the history of its past development is equally mythical. It is what the Government and the people who count in public affairs recognize and respect as such, what they think it is.

Charles A. Beard and William Beard, The AMERICAN LeViathan: THE Republic in the MACHINE AGE 39 (1930).

105. See Robert A. DAHL, Democracy AND Its Critics 190 (1989) ("[T]he views of a majority of justices of the Supreme Court are never out of line for very long with the views prevailing among the lawmaking majorities of the country."); TERRI JENNINGS PERETTI, IN Defense of a Political Court 80-132 (1999); JefFrey A. Segal \& Harold J. SPaETh, THE SUPREME COURT AND THE ATTITUdINAL MODEL 72-73 (1993); Keith E. Whittington, Taking What They Give Us: Explaining the Court's Federalism Offensive, 51 DUKE L.J. 477, 480-86 (2001).

106. President Nixon, for example, who nominated Chief Justice Rehnquist, advocated "a New Federalism" that would reverse "the trend toward ever more centralization of government in Washington D.C.," and instead direct the "flow" of "power, funds and responsibility ... from Washington to the States." Richard M. Nixon, Address to the Nation on Domestic Programs, in Pub. Papers 1969 638, 642-43 (Aug. 8, 1969); Richard M. Nixon, Special Message to the Congress on Sharing Federal Revenues with the States, in id. at 665-68 (articulating the purpose of restoring "to the States their proper rights and roles in the Federal system."); Carl W. Stenberg, Federalism in Transition: 1959-79, in READINGS IN FEDERALISM: PERSPECTIVES ON A DeCADE OF Change 3, 7-8 (Advisory Commission on Intergovernmental Relations 1989). President Reagan, who nominated Justices O'Connor, Scalia, and Kennedy, and who elevated Rehnquist to the Chief Justiceship, was elected with the declared intention to curb the size and influence of the Federal establishment and to demand recognition of the distinction between the powers granted to the Federal Government and those reserved to the States or to the people. All of us need to be reminded that the Federal Government did not create the States; the States created the Federal Government.

First Inaugural Address (Jan. 20, 1981) in InAugural AdDresses of the Presidents of the 
who are now most earnestly engaged in reviving federalist values. ${ }^{107}$ Ironically, these Justices justify their decisions by proclaiming fidelity to a Constitution that purports to remain entirely unaffected by politics. The juricentric Constitution thus enacts the very relationship between law and politics it claims to oppose.

That much said, of course courts do not and should not respond to political culture as legislatures do. They respond in ways that are mediated by the distinctive requirements of legal practice. Competent judges do not conceive of themselves as representing constituencies. Their loyalty is to the law, as they understand the law. ${ }^{108}$ The question, therefore, is how the law itself assumes political dimensions, a question that carries important normative implications for constitutional adjudication.

We begin with the observation that the Constitution is a very special kind of law. Debates about its meaning transcend the formal confines of the legal system. Americans form convictions about constitutional meaning that have roots in constitutional history and memory, and yet that also evolve in response to claims that citizens and judges make upon one another in the present. Arguments about the nature of the Constitution serve as a medium in which Americans, both in government and in mobilized social movements, debate questions of national identity and purpose. ${ }^{109}$ The

United STATES From George WASHINGTON 1789 to George Bush 1989333 (1989). President George Bush, who nominated Justice Thomas, was elected upon a Republican Party platform that reasserted "adherence to the Tenth Amendment" and that stressed judicial deference "towards State and local authority." Republican Party Issues Detailed, Long Platform, reprinted in 1988 Almanac, CONGREssional QuARTERLy 56A (1988). For a general discussion, see TIMOTHY CONLAN, NEW FEDERALISM: INTERGOVERNMENTAL REFORM FROM NiXON TO REAGAN (1988).

107. The Reagan administration in fact consciously sought to revive federalist constitutional perspectives in ways that strikingly anticipate the holdings of the contemporary Court. See, e.g., OfFICE OF LEGAL POLICY, U.S. DEP'T OF JUSTICE, Guidelines on Respecting the Limited Power Granted to the Federal Government, in GUIDELINES ON CONSTITUTIONAL LITIGATION 36-59 (1988); OfFICE OF LEGAL POLICY, U.S. DEP'T OF JUSTICE, Report to the Attorney General: The Constitution in the Year 2000: Choices Ahead in Constitutional Interpretation 130-40 (1988).

108. See, e.g., Republican Party of Minn. v. White, 122 S. Ct. 2528, 2547 (2002) (Stevens, J., dissenting) ("[T]he elected judge, like the lifetime appointee, does not serve a constituency while holding that office. He has a duty to uphold the law and to follow the dictates of the Constitution."); id. at 2551 (Ginsburg, J., dissenting):

Legislative and executive officials serve in representative capacities. They are agents of the people; their primary function is to advance the interests of their constituencies. . . . Judges, however, are not political actors. They do not sit as representatives of particular persons, communities, or parties; they serve no faction or constituency... . They must strive to do what is legally right, all the more so when the result is not the one "the home crowd" wants.

109. For recent work considering how social movements play a role in the development of constitutional understandings, see Siegel, supra note 103. For work exploring the constitutional advocacy of the labor movement, see William E. Forbath, Caste, Class, and Equal Citizenship, 98 MiCH. L. Rev. 1 (1999); William E. Forbath, The New Deal Constitution in Exile, 51 DuKE L.J. 165 (2002); Drew D. Hansen, The Sit-Down Strikes and the Switch in Time, 46 WAYNE L. REv. 49 (2000); James Gray Pope, Labor's Constitution of Freedom, 106 YALE L.J. 941 (1997); James Gray Pope, The Thirteenth Amendment Versus the Commerce Clause: Labor and the Shaping of American Constitutional Law, 1921-1957, 102 COLUM. L. REV. 1 (2002). On the constitutional advocacy of the women's movement, see Reva B. Siegel, She the People: The 
positions partisans assume in constitutional controversies are complex, interdependent, and dynamic; they are often formulated in response to the judgments of the Court itself.

Because the Court frequently speaks in the midst of wide ranging disagreements about the Constitution as a symbol of our national commitments, its decisions nourish some political perspectives and disadvantage others. Sometimes the Court backs a position that will emerge historically triumphant. In Brown v. Board of Education, ${ }^{110}$ for example, the Court encouraged and consolidated an important transformation in the nation's political culture. Sometimes, however, the Court backs a losing position. In its persistent support of labor injunctions, ${ }^{\prime \prime}$ for example, the Court lagged behind fundamental changes in the nation's understanding of industrial democracy. When interpreting the Constitution, therefore, the Court is in constant dialogue with ambient political culture. If this dialogue breaks down because the Court insists upon pressing a controversial view of the Constitution that is seriously at odds with the political views of most Americans, a crisis is sure to materialize, as it did during the time of the New Deal.

We do not mean to suggest that the Court's constitutional interpretations must at any given point in time reflect an actually existing democratic mandate. The Court can and often does embrace an understanding of the Constitution it believes to be legally correct, even if it breaks with conventional political views. But we do assert that when the Court's interpretations provoke sufficient opposition, either because they repudiate the evolving constitutional vision of the nation (as in the New Deal crisis), or because they seek to transform the constitutional vision of the nation (as in Brown), they can in the long run survive only if they generate adequate democratic support. Once the Court's critics effectively mobilize to resist the enforcement of controversial decisions or to undermine them through new appointments, those who approve the decisions must organize to defend and entrench them. The prospect of resistance and transformative appointments ensures that legal and political understandings of the Constitution remain in constant dialogue. ${ }^{112}$ Just as the Court's constitutional rulings

Nineteenth Amendment, Sex Equality, Federalism, and the Family, 115 HARV. L. REV. 947 (2002); see also sources cited infra note 144. On the constitutional advocacy of the civil rights movement, see William E. Forbath, Constitutional Welfare Rights: A History, Critique and Reconstruction, 69 FORDHAM L. REV. 1821 (2001); Randall Kennedy, Martin Luther King's Constitution: A Legal History of the Montgomery Bus Boycott, 98 Y ALE L.J. 999 (1989); Post \& Siegel, supra note 15 , at $486-502$.

110. 347 U.S. 483 (1954).

111. Truax v. Corrigan, 257 U.S. 312 (1921); Duplex Printing Press v. Deering, 254 U.S. 443 (1921).

112. Akhil Reed Amar, Popular Sovereignty and Constitutional Amendment, in RESPONDING TO IMPERFECTION 112 (Sanford Levinson ed., 1995) ("Conventional wisdom emphasizing 'countermajoritarian' judicial review to protect unpopular rights is . .. shortsighted. Presidents select judges, and presidents are elected by majorities."); cf. Barry S. Friedman, Dialogue and Judicial Review, 91 MrCH. L. REv. 577, 580-81 (1993):

[T] he process of constitutional interpretation that actually occurs does not set electorally accountable (and thus legitimate) government against unaccountable (and thus illegitimate) courts. Rather, the everyday process of constitutional interpretation integrates all three branches of government: executive, legislative, and judicial ... Courts serve to facilitate and mold the national dialogue 
can shape the nation's political life, so developments in democratic politics may have significant ramifications for the development of constitutional law. ${ }^{113}$

This is a point that we can easily miss when we are in the grip of the vision of the Constitution as entirely and exclusively law. Courts, for example, sometimes imagine that judicial legitimacy depends entirely upon fidelity to accepted norms of legal practice. But this self-accounting is at best partial. In the depths of the New Deal crisis Roosevelt did not attack conservative members of the Court for failing to be good lawyers. He attacked them for attempting to supplant the "layman's charter" of the Constitution with a technical and lifeless "lawyer's contract." "114 "[F]or one hundred and fifty years we have had an unending struggle between those who would preserve this original broad concept of the Constitution as a layman's instrument of government and those who would shrivel the Constitution into a lawyer's contract." 115 Roosevelt went so far as to suggest that the legitimacy of the Court rested primarily upon its fidelity to the mobilized political will of the nation. ${ }^{116}$

The truth, however, lies somewhere in between. Americans have traditionally understood their Constitution both as a lawyer's contract and as a layman's charter. When the Court interprets the Constitution, therefore, it must negotiate a complex set of expectations. As the Court has emphasized, its capacity to pronounce constitutional law depends upon public perception that it is acting as a court that is primarily faithful to the law. The Court risks repudiation if the public comes to believe that the Court is acting in a merely political fashion. But, at the same time, the Court's capacity to pronounce constitutional law very much depends upon the Court giving an account of the Constitution that the public can accept as its own. The Court risks repudiation if the public comes to believe that the Court's pronouncements are autocratic or despotic. The public is most prepared to submit to the constraints of the Constitution when such constraints rest on normative claims the public finds sufficiently persuasive that the experience of constraint remains an experience of self-government. The Court, in short, must render interpretations of the Constitution that are ultimately responsive to the nation's political values, yet that remain recognizably law. ${ }^{117}$

concerning the meaning of the Constitution.

See also Robert A. Dahl, Decision-Making in a Democracy: The Supreme Court as a National Policy-Maker, 6 J. PUB. L. 279, 285-91 (1957).

113. See, e.g., Balkin \& Levinson, supra note 103, at 1068 ("Partisan entrenchment through presidential appointments to the judiciary is the best account of how the meaning of the Constitution changes over time through Article III interpretation rather than through Article V amendment.").

114. PUB. PAPERS, supra note 88, at 365. See Forbath, The New Deal Constitution in Exile, supra note 109 , at 180 n.76.

115. PUB. PAPERS, supra note 88 at 363.

The lay rank and file can take cheer from the historic fact that every effort to construe the Constitution as a lawyer's contract rather than a layman's charter has ultimately failed. Whenever legalistic interpretation has clashed with contemporary sense on great questions of broad national policy, ultimately the people and the Congress have had their way.

Id. at 365 .

116. Id. at 361-68.

117. For an historical discussion of this point, see Barry S. Friedman, The History of the Countermajoritarian Difficulty, Part Three: The Lesson of Lochner, 76 N.Y.U. L. REV. 1383, 
The Court thus occupies a curiously doubled position in American life. Its authority is simultaneously legal and political. Nothing better illustrates the dual character of the Court's authority than the history of Roosevelt's Court packing plan. During the Depression, Americans were not persuaded by the Court's reiterated expression of constitutional limits on the power of the national government; they overwhelmingly returned Roosevelt to office on a legislative platform in deep conflict with the Court's constitutional vision. Yet Americans simultaneously opposed Roosevelt's plan to "pack" the Court. They wanted a Court that was both responsive to the political culture of the nation and sufficiently autonomous to pronounce constitutional law without becoming the mere mouthpiece of the political branches of government. ${ }^{18}$

The juricentric Constitution advanced in Garrett emphasizes the legal dimensions of constitutional interpretation while repressing its political character. Garrett imagines the Constitution as "in its nature the sort of 'law' that is the business of the courts-an enactment that has a fixed meaning ascertainable through the usual devices familiar to those learned in the law." 119 Because Garrett imagines the Constitution as the kind of law that speaks only to courts, it concludes that only courts can interpret the Constitution. Garrett thus fundamentally misapprehends the social relationships that actually endow the Court's constitutional pronouncements with authority. It understands constitutional interpretation simply on the model of an edict or decree. It assumes that judicial interpretations carry authority just because they are legal judgments issued by institutions designated to declare the law.

1387 (2001) ("[T]he work of constitutional judges must have both 'legal' and 'social' legitimacy.").

118. It is worth noting, also, that at no point did Roosevelt attack the Constitution itself. Instead he asked that "the American people... give their fealty to the Constitution itself and not to its misinterpreters." PUB. PAPERS, supra note 88, at 367 (emphasis in original). For a recent discussion of the New Deal conflict that explores how the public valued both judicial responsiveness and judicial independence, see Barry S. Friedman, The History of the Countermajoritarian Difficulty, Part Four: Law's Politics, 148 U. PA. L. REv. 971 (2000).

119. Antonin J. Scalia, Originalism: The Lesser Evil, 57 U. CIN. L. REv. 849, 854 (1989): Nothing in the text of the Constitution confers upon the courts the power to inquire into, rather than passively assume, the constitutionality of federal statutes. That power is, however, reasonably implicit because, as Marshall said in Marbury v. Madison, (1) "[i]t is emphatically the province and duty of the judicial department to say what the law is," (2) "[i]f two laws conflict with each other, the courts must decide on the operation of each," and (3) "the constitution is to be considered, in court, as a paramount law." Central to that analysis, it seems to me, is the perception that the Constitution, though it has an effect superior to other laws, is in its nature the sort of "law" that is the business of the courts—an enactment that has a fixed meaning ascertainable through the usual devices familiar to those learned in the law. If the Constitution were not that sort of a "law," but a novel invitation to apply current societal values, what reason would there be to believe that the invitation was addressed to the courts rather than to the legislature? One simply cannot say, regarding that sort of novel enactment, that " $[\mathrm{i}] \mathrm{t}$ is emphatically the province and duty of the judicial department" to determine its content. Quite to the contrary, the legislature would seem a much more appropriate expositor of social values, and its determination that a statute is compatible with the Constitution should, as in England, prevail. 
The Constitution, however, does not live in our society as mere ukase. Disputes about the Constitution often raise deep questions of social meaning and collective identity that are not of a kind that a democratic society settles autocratically. The legitimacy of the Constitution thus importantly depends upon its meaning remaining in an ongoing dialogue with the popular will. Recent scholarly defenders of the juricentric Constitution have overlooked this essential point. ${ }^{120}$ They fail to recognize that although constitutional law may be useful for settling disputes, the Constitution itself is not reducible to this function.

Because the Constitution possesses this dual nature, part political and part legal, the Court's efforts at constitutional interpretation must also summon a double authority. Judicial interpretations of the Constitution are always vulnerable to attack as the mere decrees of nonelected judges, as a form of potential "tyranny and usurpation," 121 the more so as judicial constitutional interpretations define themselves in opposition to the "ordinary" politics that manifest democratic accountability. The Court has typically sought to avoid such attacks by anchoring its constitutional interpretations within the political culture of the nation. ${ }^{122}$ Establishing such connections, while simultaneously preserving the Court's claim to be declaring law, is a major dimension of what Brandeis once described as the "statesmanship" of constitutional law. ${ }^{123}$

Alexander Bickel emphasized the necessity for such statesmanship when he observed that "[v]irtually all important decisions of the Supreme Court are the beginnings of conversations between the Court and the people and their representatives." ${ }^{124}$ Bickel realized that, in a democratic society, judicial declarations

120. See, e.g., Larry A. Alexander \& Frederick Schauer, On Extrajudicial Constitutional Interpretation, 110 HARV. L. REV. 1359 (1997).

121. The New Progressive Party, 20 CURRENT HISTORY 840, 841 (1924). Thus the platform of the Progressive Party, represented in the presidential election of 1924 by Senator Robert La Follette, demanded the "[a]bolition of the tyranny and usurpation of the courts, including the practice of nullifying legislation in conflict with the political, social or economic theories of the Judges." Id.

122. See Republican Party of Minnesota v. White, 122 S. Ct. 2528, 2539 (2002) (The "complete separation of the judiciary from the enterprise of 'representative government' might have some truth in those countries where judges neither make law themselves nor set aside the laws enacted by the legislature. It is not a true picture of the American system.") (Scalia, J.).

123. Melvin I. Urofsky, editor, "The Brandeis-Frankfurter Conversations," 1985 S. CT. REV. 299, 314. Even the conservative William Howard Taft agreed with the need for such statesmanship. "I do not minimize at all the importance of having Judges of learning in the law on the Supreme Bench," he wrote to George Sutherland,

but the functions performed by us are of such a peculiar character that something in addition is much needed to round out a man for service upon that Bench, and that is a sense of proportion derived from a knowledge of how Government is carried on, and how higher politics are conducted in the State. A Supreme Judge must needs keep abreast of the actual situation in the country so as to understand all the phases of important issues which arise, with a view to the proper application of the Constitution, which is a political instrument in a way, to new conditions.

Letter from William Howard Taft to George Sutherland (September 10,1922) microfilmed on William H. Taft Papers, Reel 245 (Washington, D.C., Library of Congress, 1969).

124. AleXander M. Bickel, The Supreme Court and the Idea OF Progress 91 (1978). 
of constitutional meaning become fully law only when they are taken up by the public:

[T]o say that the Supreme Court lays down the law of the land is to state the ultimate result, following upon a complex series of events, in some cases, and in others it is a form of speech only. The effectiveness of the judgment universalized depends upon consent and administration.

The Court is often incapable of generating the necessary consent by itself, and it does not command the resources of administration. ${ }^{125}$

Once we appreciate the dual character of judicial authority, the Court's relationship with the representative branches of government acquires special significance, as Bickel well appreciated. The representative branches of government have traditionally played an important role in shaping our constitutional order, ${ }^{126}$ and not merely in matters concerning the economy or foreign affairs, where judicial authority is generally thought to be weakest. It is this democratic dimension of our constitutional tradition that Garrett would repress. ${ }^{127}$

During the past half century, Section 5 legislation has been a significant medium for democratic influence on the development of our constitutional culture. The Court's recent Section 5 cases, culminating in Garrett, have adopted a juricentric standard of

125. Id. at 91-92.

126. Recent works in the field of American political development that examine constitutionalism in the representative branches include LOUIS FISHER, CONSTITUTION Dialogues: InTERPRetation as Political Process (1988); STEPHEN M. Griffin, AMERICAN Constitutionalism (1996); and Keith E. Whittington, Constitutional Construction: Divided Powers and Constitutional MEaning (1999). Scholars of American political development explore the life of the Constitution in the representative branches of government in ways that those teaching in law schools generally do not-though the list of prominent law scholars who do not fit this generalization continues to grow. They include Bruce Ackerman, Jack Balkin, Sandy Levinson, and Mark Tushnet. For an account of the disciplinary divide, and a review of some of the recent scholarship in the field, see Mark A. Graber, Constitutional Politics and Constitutional Theory: A Misunderstood and Neglected Relationship, 27 LAW \& Soc. INQUiRY 309 (2002) (reviewing LuCAS A. POWE, THE WARREN COURT AND AMERICAN POLITICS (2000)); Robert W. Bennett, Counter-Conversationalism and the Sense of Difficulty, 95 Nw. U. L. REV. 845, 850-51, 904 (2001) ("In the counter-majoritarian literature, the turn to interpretation and the effort to place the courts in a larger democratic context managed largely to ignore each other. ... The difference may be partly a function of the different disciplinary homes of those who pursued the two strands.")

127. Challenging the Court's assertion that it has exclusive authority to interpret the Constitution, Larry Kramer has observed, there is "a world of difference" between allowing the Court to have "the last word" in a particular constitutional controversy, and granting the Court authority to pronounce "the only word" about the Constitution's meaning. Larry D. Kramer, Foreword: We the Court, 115 HARv. L. Rev. 5, 13 (2001) (emphasis in original). Kramer identifies this difference as that "between judicial supremacy and judicial sovereignty." Id. Kramer offers a wide-ranging history of the doctrinal arrangements that have accommodated the twin ideals of judicial supremacy and popular constitutionalism, observing, "[w]e may choose to accept judicial supremacy. . . . But it does not follow either that the Court must wield its authority over every question or that, when it does, the Court can dismiss or too quickly supplant the views of other, more democratic institutions." $1 d$. 
review for Section 5 legislation that seeks to prevent Congress from expressing the independent constitutional perspective of a democratically elected legislature. Because the Court now views any variance between legislative and adjudicative enforcement of the Fourteenth Amendment as suspect, it effectively approaches every exercise of Section 5 power as an incipient constitutional violation. The Court has invalidated civil rights legislation at a rate that seems designed to intimidate Congress in the exercise of its Section 5 power. In so doing, the Court is deliberately suppressing a vibrant constitutional conversation between Congress and the Court that has persisted throughout the second half of the twentieth century.

Garrett advances its vision of the juricentric Constitution as though it were logically compelled by Marbury, as though it were the necessary foundation of judicial review itself. But this is simply incorrect. The Court has never enjoyed an exclusive prerogative to interpret the Constitution, ${ }^{128}$ and in fact throughout its history the Court has itself employed diverse means to encourage the participation of the representative branches of government in the formation of constitutional meaning. It has had to depend upon the political support of the popular branches even to realize its core mission of articulating and protecting constitutional rights. Whereas Garrett presents the Constitution as the exclusive preserve of the Court, in this final section of the Article we consider a variety of important ways in which the interpretation and enforcement of constitutional rights depend upon an ongoing and vibrant relationship between Congress and the Court.

The point can clearly be seen in the history of Brown v. Board of Education. ${ }^{129}$ Although Brown attempted to infuse new meaning into the Equal Protection Clause, the Court was not equipped to bring the nation to embrace this controversial interpretation of the Fourteenth Amendment. ${ }^{130}$ As Judge Wisdom famously observed,

128. See, e.g., Keith E. Whittington, Extrajudicial Constitutional Interpretation: Three Objections and Responses, 80 N.C. L. REV. 773, 848 (2002):

The authority to interpret the Constitution is shared by multiple institutions and actors within our political system, and tends to flow among them over time rather than remain fixed in a stable hierarchical or segmented distribution. The question is less whether we should have extrajudicial constitutional interpretation, than how we should evaluate it and how various constitutional interpreters should relate to one another as they engage in their common task. ... Once we recognize that extrajudicial constitutional interpretation can co-exist with judicial review, then the normative case for and against extrajudicial constitutional interpretation primarily goes to the question of how much deference the judiciary should show to other political actors in formulating doctrine and evaluating the constitutionality of legislation and how much deference nonjudicial actors should show the judiciary in articulating constitutional understandings and taking political actions.

129. 347 U.S. 483 (1954).

130. See BiCKEL, supra note 124, at 92 ("[E]ven now the effectiveness of Brown as law largely depends on the will and the resources that are brought to its administration, and these are in the control, not of the Court, but of the political institutions in the states and in Washington."). 
"[t] he courts acting alone have failed." ${ }^{131}$ Brown had to be taken up by a broad-based social movement and enforced by the executive and legislative branches before its legal values could become a living constitutional reality. Acting alone, the Court had neither the legitimacy nor authority to transform popular constitutional understandings that were rooted in an entrenched system of racial apartheid. ${ }^{132}$

The Court understood from the very beginning that these understandings could not be reformed by mere judicial decree. That is why in Brown itself the Court had asked for briefing on the question of whether "future Congresses might, in the exercise of their power under Section 5 of the Amendment, abolish" school segregation, even if "neither the Congress submitting nor the States in ratifying the Fourteenth Amendment understood that compliance with it would require the immediate abolition of segregation in public schools." 133 In so doing "the Justices acknowledged among themselves that, in pragmatic terms at least, nothing would follow from the Brown decision unless support voluntarily came from the President and Congress." 134 The Justices understood that entrenching the constitutional vision of Brown required the kind of political mobilization that altered the nation's sense of itself.

Archibald Cox was thus exactly right to remark that "the principle of Brown $v$. Board of Education became more firmly law after its incorporation into the Civil Rights Act of 1964." ${ }^{135}$ Although our legal system invests Supreme Court decisions with finality, the Court's judgments cannot be incorporated into the constitutional selfconception of the country until they are taken up by citizens outside the courts. The democratic authority of Brown derived not only from the Court's fidelity to acts of Article $\mathrm{V}$ lawmaking that occurred in the Nineteenth century, but also from acts of social mobilization and congressional enforcement that occurred in the Twentieth century. ${ }^{136}$ Judicial decrees alone do not create the living reality of constitutional norms, as the juricentric Constitution would encourage us to believe.

If the participation of the popular branches may be necessary for legitimating and entrenching the Court's considered constitutional judgments, such participation can also be an important resource for the Court's own deliberations about how to interpret the Constitution. This point can perhaps most plainly be seen in the development of sex discrimination law under Section 1 of the Fourteenth Amendment. This law derived

131. United States v. Jefferson County Bd. of Educ., 372 F.2d 836, 847 (5th Cir. 1966), aff'd en banc, 380 F.2d 385 (5th Cir. 1967) (emphasis in original); cf. Gerald N. Rosenberg, THE Hollow Hope: Can Courts Bring About Social Change? 52 (1991) ("The numbers show that the Supreme Court contributed virtually nothing to ending segregation of the public schools in the Southern states in the decade following Brown."). For a comprehensive discussion, see $i d$. at 39-157.

132. See Bush v. Orleans Parish Sch. Bd., 138 F. Supp. 337, 342 (E.D. La. 1956), aff d, 242 F.2d 156 (5th Cir. 1957) (Wright, J.) ("The problem of changing a people's mores, particularly those with an emotional overlay, is not to be taken lightly.").

133. Brown v. Bd. of Educ., 345 U.S. 972, 972 (1953).

134. ROBERT A. BURT, THE CONSTITUTION IN CONFLICT 295 (1992).

135. Cox, supra note 18 , at 94.

136. Cf. BURT, supra note 134, at 303 ("The condemnation of race segregation in the 1964 Civil Rights Act . . . bestowed legitimacy on the Supreme Court's ruling in Brown v. Board of Education in a way that the Court could never have accomplished on the basis of its authority alone."). 
neither from the abstract text of the Equal Protection Clause nor from the original intent of the Framers of the Fourteenth Amendment. It instead evolved from important changes in the nation's sense of the fundamental requirements of equality. ${ }^{137}$ The Court's jurisprudence of sex discrimination illustrates how the Court's constitutional interpretations can draw strength and legitimacy from a dialogic relationship to contemporary political culture. ${ }^{138}$

If we closely examine exactly how the Court came to find discrimination on the basis of sex to be constitutionally suspect, we find that by the time that a plurality of the Court was first prepared to advance the notion that classifications based upon sex might receive elevated scrutiny in 1973 in Frontiero $v$. Richardson, ${ }^{139}$ Congress had been prohibiting sex discrimination for over nine years and an active social movement had mobilized to secure vigorous enforcement of federal law. ${ }^{140}$ In the Equal Employment Opportunity Act of 1972, Congress used Section 5 power to apply Title VII's prohibition of sex discrimination in employment to states, ${ }^{141}$ reasoning that "[d]iscrimination against women is no less serious than other forms of prohibited employment practices and is to be accorded the same degree of social concern given to any type of unlawful discrimination." 142

Congress thus regarded sex discrimination as a serious constitutional problem at a time when the Court was still using rational basis review to scrutinize sex-based classifications. ${ }^{143}$ Eventually the Court incorporated this congressional understanding into its own legal interpretation of the Fourteenth Amendment. The plurality opinion in Frontiero was prepared generously and candidly to acknowledge the influence of Congress's independent understandings of the nature of "invidious" discrimination:

We might also note that, over the past decade, Congress has itself manifested an increasing sensitivity to sex-based classification. In Tit. VII of the Civil Rights Act of 1964, for example, Congress expressly declared that no employer, labor union, or other organization subject to the provisions of the Act shall discriminate against any individual on the basis of "race, color, religion, sex, or national origin." Similarly, the Equal Pay Act of 1963 provides that no employer... "shall

137. For discussion, see Post \& Siegel, supra note 15, at 513-22.

138. See, e.g., Ruth Bader Ginsburg, Speaking in a Judicial Voice, 67 N.Y.U. L. REv. 1185, 1198 (1992) ("[J]udges play an interdependent part in our democracy. They do not alone shape legal doctrine but ... they participate in a dialogue with other organs of government, and with the people as well.").

139. 411 U.S. 677 (1973).

140. The National Organization of Women (NOW) was founded during this period in order to pressure the federal government into enforcing the law against sex discrimination in employment that had been included in the Civil Rights Act of 1964. On the founding and early development of NOW, see JO FREEMAN, THE POLITICS OF WOMEN'S LIBERATION 71-102 (1975); CYNTHIa HaRrison, ON ACCOUNT OF SEX: The Politics of WoMEN's Issues, 1945-1968, at 192-209 (1988).

141. Equal Employment Opportunity Act of 1972, Pub. L. No. 92-261, § 2, 86 Stat. 103,103 (codified at 42 U.S.C. $2000 \mathrm{e}(2000)$ ). See Fitzpatrick v. Bitzer, 427 U.S. 445 (1976).

142. H.R. REP No. 92-238, at 5 (1971), reprinted in 1972 U.S.C.C.A.N. 2137, 2141 (Equal Opportunity Act of 1972); see also S. REP. NO. 92-415, at 7-8 (1971).

143. See, e.g., Reed v. Reed, 404 U.S. 71, 76 (1971); Goesaert v. Cleary, 335 U.S. 464 (1948). 
discriminate ... between employees on the basis of sex." And $\S 1$ of the Equal Rights Amendment, passed by Congress on March 22, 1972, and submitted to the legislatures of the States for ratification, declares that "[e]quality of rights under the law shall not be denied or abridged by the United States or by any State on account of sex." Thus, Congress itself has concluded that classifications based upon sex are inherently invidious, and this conclusion of a coequal branch of Government is not without significance to the question presently under consideration. ${ }^{144}$

Frontiero viewed differences in congressional and judicial responses to sex discrimination as an opportunity for education, not as evidence of insubordination. Had the Court been committed to the juricentric Constitution in the 1970s, it would have attempted to silence Congress rather than to learn from it. Just as Garrett proscribes Congress's efforts to extend to states the disability provisions of Title I of the ADA, so the Court would have prevented Congress from extending to states the sex discrimination provisions of Title VII.

The contrast between Frontiero and Garrett could not be clearer. Not only does Garrett ignore the constitutional views of nonjudicial actors, it strives to suppress them as potentially threatening to the Court's own monopoly on constitutional interpretation. Garrett assumes that upholding Section 5 legislation that differs from Section 1 case law would "allow Congress to rewrite the Fourteenth Amendment law laid down by this Court." ${ }^{145}$ For this reason, Garrett aggressively prohibits Congress from addressing questions of constitutional meaning except in the guise of "a lower court." ${ }^{146}$ But when Congress was developing its understanding of the constitutional dimensions of sex discrimination in the 1960s and 1970s, it was not proceeding as a "lower court." It was proceeding as a political body attentive to the American people's evolving understanding of their own constitutional ideals. The Court, in turn, welcomed Congress's active engagement with constitutional questions. In an era when the Court was beginning to interpret the Constitution to prohibit race- and sex-based state action, the Court was acutely aware of the many ways that the project of understanding and implementing constitutional commitments required for its fulfillment the participation and support of the political branches of government.

Today we have forgotten these aspects of our civil rights tradition. In fact most popular and professional accounts of the Second Reconstruction recall the project of dismantling Jim Crow as the heroic work of the Court courageously confronting

144. Frontiero, 411 U.S. at $687-88$ (Brennan, J., plurality opinion) (footnotes omitted \& emphasis added). For discussion of the role that social movement advocacy played in shaping the understanding of Congress and the Court in this period, see Serena Mayeri, "A Common Fate of Discrimination": Race-Gender Analogies in Legal and Historical Perspective, 110 YALE L.J. 1045, 1069-79 (2001) (discussing the women's movement's litigation strategies under the Fourteenth Amendment from the mid-1960s to the mid-1970s); Serena Mayeri, Strategic Feminism and Constitutional Change, at 21-28 (2001) (unpublished manuscript, on file with authors) (discussing the movement's interpretive and amendatory constitutional claims; Siegel, supra note 103, at 307-14 (tracing the ways in which social movement mobilization played a role in shaping the constitutional understandings of Congress and the Court in the 1970s).

145. Garrett, 531 U.S. at 374.

146. Id. at 383 (Breyer, J., dissenting); Colker \& Brudney, supra note 58, at 113. 
popular resistance at Little Rock. Cooper v. Aaron ${ }^{147}$ has thus become emblematic of the Court's stance during the Civil Rights Era, and Cooper, shorn of its institutional context, has become a symbol of raw judicial supremacy. ${ }^{148}$ These simplified, courtcentered accounts efface the crucial role played by social movements and the representative branches of government in challenging segregation and advancing new forms of equality; they also ignore the many ways in which the Court itself encouraged and relied upon popular participation in the project of entrenching new understandings of the Equal Protection Clause. We have somehow suppressed these crucial collaborative relationships, and instead enshrined the Court as the primary author of the modern civil rights tradition. If the juricentric Constitution invoked in cases from Boerne to Garrett has any credibility at all, it is by reason of this romantic narrative of the Court's heroic and lonely role in defending civil rights at Little Rock. The juricentric Constitution perversely, craftily, brilliantly turns this narrative into a basis for attacking the Congress's role in enacting civil rights legislation.

This narrative, however, fundamentally misrepresents the facts of the matter. The very Court that famously and vigorously defended judicial prerogatives in Cooper was also the Court that in Katzenbach v. Morgan ${ }^{149}$ confidently invited Congress to engage in processes of constitutional interpretation. In Katzenbach the Court stressed that "correctly viewed, $\S 5$ is a positive grant of legislative power authorizing Congress to exercise its discretion in determining whether and what legislation is needed to secure the guarantees of the Fourteenth Amendment." 150 Cooper and Katzenbach were decided by virtually the same Court and at virtually the same time. Evidently the Warren Court saw nothing contradictory in simultaneously upholding the rule of law and deferring to Congress's Section 5 authority. Although at times the Court insisted that the judiciary have the last word about constitutional meaning, at other times it encouraged vigorous congressional participation in the formation of constitutional culture. Notwithstanding its pronouncements in Cooper, the Court never imagined that the Constitution spoke only to judges.

The Court was in fact so intent upon mobilizing the support of the popular branches of government that it repeatedly crafted holdings that endowed Congress with wide latitude to express its own constitutional understandings, in the full knowledge that

147. 358 U.S. 1 (1958).

148. But cf. BURT, supra note 134, at 296:

In his original draft of the Court's opinion in Cooper v. Aaron, Justice Brennan lightly mentioned the possibility that "the problem of securing the constitutional rights of the school children by individual law suits may be such as to warrant the attention of the Congress in formulating laws pursuant to Section 5 of the Fourteenth Amendment." But Justice Clark objected, admonishing Brennan to omit any reference to Congress and instead add "hoopla" about the supremacy of judicial authority.

149. 384 U.S. 641 (1966).

150. Id. at 651. Chief Justice Warren's position in conference in Katzenbach was that "[C]ongress may legislate against discrimination against voting under $\S 5$ of the Fourteenth Amendment. Congress need not make findings or justify its actions if we can justify its conduct on any rational basis." The Supreme Court IN CONFERENCE 1940-1985: THE PrIVATE Discussions Behind Nearly 300 Supreme Court Decisions 827 (Del Dickson ed. 2001) [hereinafter SUP. CT. IN CONFERENCE]. 
these understandings would differ from the standards that the Court was prepared itself to enforce in litigation. The Court brought this commitment to bear not only in its interpretation of the enforcement clause of the Thirteenth Amendment, ${ }^{151}$ but also in its construction of Section 5 of the Fourteenth Amendment:

A construction of $\S 5$ that would require a judicial determination that the
enforcement of the state law precluded by Congress violated the Amendment, as a
condition of sustaining the congressional enactment, would depreciate both
congressional resourcefulness and congressional responsibility for implementing
the Amendment. It would confine the legislative power in this context to the
insignificant role of abrogating only those state laws that the judicial branch was
prepared to adjudge unconstitutional, or of merely informing the judgment of the
judiciary by particularizing the "majestic generalities" of $\S 1$ of the Amendment.

In the era between Katzenbach and Boerne, the Court fashioned its Section 5 jurisprudence so as to promote a dialogue with Congress about the meaning of the Constitution. The Court encouraged this dialogue through a variety of doctrinal techniques that authorized Congress to enact Section 5 legislation, while exempting the Court from the obligation of incorporating congressional understandings of the Constitution into its own interpretations of Section 1. These techniques often rendered ambiguous the exact relationship between Section 5 legislation and the Court's own views of Section 1 , thereby recognizing the distinct constitutional roles of Congress and the Court in ways that respected the autonomy of each. Katzenbach $v$. Morgan was in this regard paradigmatic.

Katzenbach employed the familiar practice of judicial deference for new and creative jurisprudential ends. In Katzenbach, the Court announced for the first time that it would defer to Congress's power to enact legislation pursuant to Section 5 . This deference had the effect of authorizing a variety of distinct possible relationships among the Court, Congress, and the Constitution. Because legislation differs from adjudication, every Section 5 statute will vary in some respect or another from the Court's Section 1 decisions. These variations can arise for many different reasons. Variations may occur because Congress has made an independent judgment about the constitutional meaning of Section 1 in the course of exercising its power to enforce the Fourteenth Amendment. ${ }^{153}$ Or variations may simply reflect Congress's earnest effort

151. The Court decided a series of cases that led inexorably to the conclusion that "Congress, through its enforcement power under Section Two of the Thirteenth Amendment is empowered, to control conduct that does not come close to violating Section One directly." United States v. Nelson, 277 F.3d 164, 185 (2d Cir. 2002).

152. Katzenbach, 384 U.S. at 648-49 (footnote omitted). For a discussion of the Court's decisions during the Civil Rights Era, see Post \& Siegel, supra note 15, at 494-502.

153. It is a debatable question whether the Court in Katzenbach explicitly ceded to Congress the blunt authority to define the meaning of constitutional guarantees. In conference in Katzenbach Justice White took the position:

This is Congress's definition of "equal protection," and it is valid. ... In light of this act of Congress, I would uphold the act. That means that we would allow Congress to declare what is a denial of equal protection. Without the statute, I would have trouble. But if it is not too far out of line in [sic] is O.K. 
to interpret the Court's own decisions and apply the constitutional principles they announce to different practical contexts. ${ }^{154}$ Or variations may have nothing to do with questions of interpretation, and instead merely reflect the fact that legislative and adjudicative enforcement of the Fourteenth Amendment diverge by reason of the discrete fact-finding capacities or remedial power ${ }^{155}$ of the two institutions, so that Section 5 statutes can assume the distinctive character of "prophylactic legislation" designed "to remedy and to deter violation of rights" otherwise articulated by the Court. ${ }^{156}$ Whether these various relationships among Congress, the Court and the Constitution are more or less acceptable depends on one's view of separation of powers.

Katzenbach applied to Section 5 power the same standards of deference that the post-New Deal Court has applied to every other grant of congressional authority. ${ }^{157}$ Just as the Court's deference to Commerce Clause legislation reflected "a strong presumption of constitutionality," "158 so Katzenbach's deference to Section 5 legislation expressed the presumption that such statutes were a valid exercise of Congress's constitutional power to enforce the Fourteenth Amendment. ${ }^{159}$ The ultimate effect of

SUP. CT. IN CONFERENCE, supra note 150, at 828. This understanding of Section 5 is similar to the position that Justice White implied in his opinion for the Court in City of Cleburne $v$. Cleburne Living Ctr., 473 U.S. 432, $439-42$ (1985):

The Equal Protection Clause of the Fourteenth Amendment commands that no State shall "deny to any person within its jurisdiction the equal protection of its laws," which is essentially a direction that all persons similarly situated should be treated alike. ... Section 5 of the Amendment empowers Congress to enforce this mandate, but absent controlling congressional direction, the courts have themselves devised standards for determining the validity of state legislation or other official action that is challenged as denying equal protection. The general rule is that legislation is presumed to be valid and will be sustained if the classification drawn by the statute is rationally related to a legitimate state interest....

White also strongly hinted at this position in his opinion for the Court in Washington v. Davis, 426 U.S. 229 (1976). For a discussion, see Post \& Siegel, supra note 15, at 464-65, 468-69.

154. This was in essence Gottesman's argument to the Court in Garrett. See supra text accompanying notes $46-48$.

155. See, e.g., Fullilove v. Klutznick, 448 U.S. 448, 483 (1980) (Burger, C.J.) ("It is fundamental that in no organ of government, state or federal, does there repose a more comprehensive remedial power than in the Congress, expressly charged by the Constitution with competence and authority to enforce equal protection guarantees.").

156. Kimel v. Fla. Bd. of Regents, 528 U.S. 62, 81, 88 (2000). Garrett still purports to authorize such prophylactic and remedial legislation. See supra note 41 .

157. On the concept of a "spectrum of deference to the political branches' interpretation of the Constitution," see Rachel E. Barkow, More Supreme than Court? The Fall of the Political Question Doctrine and the Rise of Judicial Supremacy, 102 COLUM. L. REV. 237, 319 (2002).

158. United States v. Five Gambling Devices, Etc. 346 U.S. 441, 449 (1953) (Jackson, J.):

This Court does and should accord a strong presumption of constitutionality to Acts of Congress. This is not a mere polite gesture. It is a deference due to deliberate judgment by constitutional majorities of the two Houses of Congress that an Act is within their delegated power or is necessary and proper to execution of that power.

159. From this perspective, it is clear that Garrett's refusal to defer to Section 5 legislation, 
such deference, however, was to relieve the Court of the obligation of determining exactly why this Section 5 legislation differed from the Court's own interpretations of Section 1. By deferring to Congress's judgment, the Court could decide cases without ever reaching the merits of Congress's precise view of the Fourteenth Amendment. Katzenbach deference thus rendered it impossible to know in any given case whether the Court had approved a Section 5 statute because the Court believed Congress had accurately apprehended Section 1 rights as the Court was prepared to enforce them in Section 1 adjudication.

Katzenbach blurred the relationship between statutory and constitutional standards, turning analytic imprecision to constructive institutional ends. By rendering ambiguous the relationship between Section 5 legislation and Section 1 case law, the Court encouraged Congress to exercise its power to enact Section 5 legislation and yet also reserved its own authority to utter the last word about the meaning of Section 1 of the Fourteenth Amendment.

The Court appears to have cultivated this same ambiguity by a variety of distinct methods. Its treatment of the Civil Rights Act of $1964^{160}$ is exemplary. Although Congress insisted that it possessed authority under Section 5 to enact the statute, ${ }^{161}$ the Court repeatedly refused to address the constitutionality of Congress's claim to this power. ${ }^{162}$ The Court nevertheless readily and unselfconsciously deployed constitutional standards to interpret the statutory requirements of Title VII, ${ }^{163}$ and it approved the wholesale extension of Title VII to the states as "an appropriate method of enforcing the Fourteenth Amendment" under Section 5. ${ }^{164}$ For decades the Court has consigned the precise status of the antidiscrimination standards contained in the Civil Rights Act

see supra text accompanying notes 56-58, reflects the exactly opposite presumption. Garrett seems to assume that Section 5 legislation is somehow suspect because it is potentially unfaithful to the Court's view of the Constitution. By requiring Congress meticulously to account for variances between legislative and adjudicative enforcement of the Fourteenth Amendment, Garrett treats every exercise of Section 5 power as though it were an illicit effort by Congress to wrest interpretive authority away from the Court. Judicial review conducted on these premises chills rather than stimulates conversation between Congress and the Court about the constitutional principles underlying the nation's civil rights commitments, and so creates interbranch relations that are diametrically opposite to those fostered by Katzenbach.

160. Pub. L. No. 88-532, 78 Stat. 241 (1964).

161. For a discussion, see Post \& Siegel, supra note 15, at 447 n.22.

162. Hazelwood Sch. Dist. v. United States, 433 U.S. 299, 306 n. 12 (1977):

Their petition for certiorari and brief on the merits did raise a second question:

"Whether Congress has authority under Section 5 of the Fourteenth Amendment to prohibit by Title VII of the Civil Rights Act of 1964 employment practices of an agency of a state government in the absence of proof that the agency purposefully discriminated against applicants on the basis of race." That issue, however, is not presented by the facts [sic] this case.

See also Katzenbach v. McClung, 379 U.S. 294, 304 (1964); Heart of Atlanta Motel v. United States, 379 U.S. 241, 258 (1964).

163. See, e.g., Gen. Elec. Co. v. Gilbert, 429 U.S. 125, 132-40 (1976).

164. City of Rome v. United States, 446 U.S. 156, 179 (1980) (quoting Fitzpatrick v. Bitzer, 427 U.S. 445 (1976)). Whether this holding can survive the Court's current commitment to the juricentric Constitution is an open question. See, e.g., Crum v. Ala. (In re Employment Discrimination Litig. Against Ala.), 198 F.3d 1305, 1322 (1 1 th Cir. 1999). 
of 1964 to a kind of legal limbo.

During the period between Brown and Boerne, Congress responded to the Court's encouragement by using its Section 5 power to enact civil rights statutes that transformed the enforcement of antidiscrimination norms into a major responsibility of the national government. ${ }^{165}$ The Court, in turn, systematically refused to clarify the status of this legislation, ${ }^{166}$ reserving the question on so many occasions that its decisionmaking appears to have been deliberate. For ease of nomenclature, we can call this apparent policy of maintaining ambiguity about the constitutional status of statutory norms the "Katzenbach approach."

The Katzenbach approach served important constitutional purposes. We have already identified two such functions. First, legislative and judicial understandings of Section 1 will differ insofar as Congress and the Court possess distinct institutional competencies, resources, and forms of democratic responsiveness. The Katzenbach approach allowed for play in the joints ${ }^{167}$ by authorizing institutionally differentiated enforcement of the Fourteenth Amendment without committing the Court to any precise theory of the distinction between legislative and judicial enforcement of constitutional rights.

Second, the Katzenbach approach invited congressional participation in the development of constitutional understandings. Constitutional culture has evolved in ways that benefit not only from Congress's unique legislative competencies, but also from Congress's political responsiveness. Under the Katzenbach approach, the Court could authorize Congress to test possible meanings of the Equal Protection Clause,

165. See, e.g., Americans with Disabilities Act of 1990, 42 U.S.C. $\S 12,101(b)(3)(2000)$; Violence Against Women Act of 1994, 42 U.S.C. $\$ 13981$ (a) (2000); Freedom of Access to Clinic Entrances Act of 1994, Pub. L. No. 103-259, § 2, 108 Stat. 694; Civil Rights Act of 1964, Pub. L. No. 88-352, § 201, 78 Stat. 241, 243; Educ. \& Labor Comm., Equal Employment Opportunity Act of 1972, H.R. REP. No. 92-238, at 19 (1971), reprinted in 1972 U.S.C.C.A.N. 2137, 2154; S. Judiciary Comm., Civil Rights Act of 1968, S. REP. No. 90-721, at 7 (1967), reprinted in 1968 U.S.C.C.A.N. 1837, 1843.

166. See, e.g., Curtis v. Loether, 415 U.S. 189, 198 n.15 (1974) (deciding whether jury trials are required under Fair Housing title of the Civil Rights Act of 1968) ("We therefore have no occasion to consider in this case any question of the scope of congressional power to enforce $\$ 2$ of the Thirteenth Amendment or $\S 5$ of the Fourteenth Amendment."); Griffin v. Breckenridge, 403 U.S. 88, 107 (1971) (discussing the constitutionality of 42 U.S.C. $\S 1985(3)$, which prohibits conspiracies to interfere with civil rights) ("[T]he allegations of the complaint in this case have not required consideration of the scope of the power of Congress under $\S 5$ of the Fourteenth Amendment."); United States v. Guest, 383 U.S. 745, 755 (1966) (reviewing an indictment under 18 U.S.C. $\S 241$ (1964), which criminalizes conspiracies against "the free exercise or enjoyment of any right or privilege secured to him by the Constitution or laws of the United States") ("Since we therefore deal here only with the bare terms of the Equal Protection Clause itself, nothing said in this opinion goes to the question of what kinds of other and broader legislation Congress might constitutionally enact under $\S 5$ of the Fourteenth Amendment. ..."). Cf. Franklin v. Gwinnett County Pub. Sch., 503 U.S. 60, 75 n.8 (1992) (choosing not to reach the question of whether Congress relied on its Section 5 powers in addition to its Spending Clause powers when it enacted Title IX).

167. "We must remember that the machinery of government would not work if it were not allowed a little play in its joints." Bain Peanut Co. v. Pinson, 282 U.S. 499, 501 (1931) (Holmes, J.). 
which the Court was then able to evaluate before articulating its own Section 1 jurisprudence. ${ }^{168}$ Sometimes, as in the case of sex discrimination, the Court responded by incorporating congressional meanings into its own Section 1 standards. And sometimes, as in the case of the disparate impact methodology of Title VII, the Court distinguished constitutional from statutory standards on the ground that "the calculus of effects ... is a legislative and not a judicial responsibility." 169 The Court could thus respond as it wished to Congress's understanding of constitutional values. By allowing each branch to exercise its role in enforcing the Constitution without unduly constraining the other, the Katzenbach approach permitted the Constitution as law, and the Constitution as the repository of the nation's deepest political commitments, to maintain a constructive if uneasy coexistence.

It is not clear that even the Katzenbach Court itself fully appreciated the profound implications of its own doctrinal method. In Katzenbach Harlan famously charged that if Congress were given the discretion to use its Section 5 power in a way that effectively defined "the substantive scope of the" Fourteenth Amendment, Congress could also "exercise its $\S 5$ 'discretion' by enacting statutes so as in effect to dilute equal protection and due process decisions of this Court." ${ }^{\text {"170 }}$ Harlan feared that if Congress were authorized to interpret the Constitution, it might constrain and preempt judicial protections for constitutional rights. The Court responded to Harlan by advancing what later became known as the "ratchet" argument: ${ }^{171}$

\begin{abstract}
Contrary to the suggestion of the dissent $\ldots \S 5$ does not grant Congress power to exercise discretion in the other direction and to enact "statutes so as in effect to dilute equal protection and due process decisions of this Court. We emphasize that Congress' power under $\S 5$ is limited to adopting measures to enforce the guarantees of the Amendment; $\S 5$ grants Congress no power to restrict, abrogate, or dilute these guarantees. ${ }^{172}$
\end{abstract}

The ratchet argument was almost instantly controversial, because in situations of conflicting rights it is hard to distinguish expanding a right from diluting it, and because it is baffling why a power to define a right can be effective in only one "direction."

In retrospect, it is clear that Harlan's challenge was premised on the assumption that a legitimate exercise of Section 5 power would bind judicial interpretations of Section 1. The very structure of "deference" created by Katzenbach, however, undercuts this assumption, because it obscures the constitutional basis for upholding Section 5

168. Just as federalism is sometimes defended because it creates laboratories for "novel social and economic experiments without risk to the rest of the country," New State Ice Co.v. Liebmann, 285 U.S. 262, 311 (1932) (Brandeis, J., dissenting), so the Katzenbach approach permitted Congress to "experiment" with possible meanings of Section 1 without risk to the Court's own Section 1 jurisprudence.

169. Pers. Adm'r v. Feeney, 442 U.S. 256, 272 (1979). In Washington v. Davis, 426 U.S. 229 (1976), the Court hinted that Section 1 norms, when enforced by a legislature rather than by a court, might incorporate a calculus of effect. See id. at 247-48.

170. Katzenbach, 384 U.S. at 668 (Harlan, J., dissenting).

171. The label originated in William Cohen, Congressional Power to Interpret Due Process and Equal Protection, 27 STAN. L. REv. 603, 606 (1975).

172. Katzenbach, 384 U.S. at 651 n.10. 
legislation. Katzenbach effectively decouples the exercise of Section 5 power from judicial interpretations of Section 1. For this reason the Court need not have advanced the ratchet argument at all. It need only have observed that deferring to Congress's power to enact Section 5 legislation does not commit the Court to any particular interpretation of Section 1. The Court can still hold unconstitutional any exercise of Section 5 power that it believes violates a Section 1 right, in the same way that it can hold unconstitutional any exercise of Commerce Clause power that it believes violates a Section 1 right. The Court's failure to advance this argument shows that it was not yet fully in command of the implications of its own doctrine. ${ }^{173}$

The Court was nonetheless perfectly clear about what it wanted to achieve, for in the years after Katzenbach it repeatedly responded to federal civil rights legislation in ways that demonstrated a readiness to accept Congress's judgment about how to enforce constitutional norms, while simultaneously preserving the Court's own authority to declare the Constitution's meaning. Using doctrinal techniques ranging from deference, ${ }^{174}$ to deliberate equivocation, ${ }^{175}$ to the explicit acknowledgement that the nature of constitutional rights could vary depending upon whether they were enforced by Congress or by the judiciary, ${ }^{176}$ the Court effectively decoupled Section 5 power from judicial interpretations of Section 1. Congress accepted the authority attributed to it by the Court by enacting legislation that sought to vindicate constitutional ideals of liberty and equality.

This is the institutional background that produced the ADA. The ADA was based upon a "vast legislative record" that included " 13 congressional hearings" and the report of a "special task force" that "held hearings in every State, attended by more than 30,000 people, including thousands who had experienced discrimination first hand." 177 This record served to educate Congress and the nation about the "prejudice," the "stereotypic assumptions," and the "purposeful unequal treatment" faced by persons with disabilities. ${ }^{178}$ It served to mobilize the political will to address these injustices. In signing the ADA President Bush was moved to characterize the legislation as "the full flowering of our democratic principles" that gives "clear

173. The notion of institutionally differentiated enforcement of Section 1 was in 1966 quite new and unassimilated. In Heart of Atlanta Motel v. United States, 379 U.S. 241 (1964), for example, Justices Douglas and Goldberg had each written concurring opinions assuming that Section 5 power and judicial enforcement of Section 1 were tightly coupled. See id. at 280 (Douglas, J., concurring); id. at 376-77 (Goldberg, J., concurring). The debates over the 1964 Civil Rights Act were conducted on a similar assumption. See Post \& Siegel, supra note 15, at 497. Justice Black's dissent in Bell v. Maryland, 378 U.S. 226 (1964), is an early example of a Justice prepared to recognize and accept a conceptual distinction between congressional statutes enacted pursuant to Section 5 and judicial enforcement of Section 1. Id. at 342-43 (Black, J. dissenting). For a discussion of the Court's rapid assimilation of this idea, see Post \& Siegel, supra note 15, at 497-501.

174. Katzenbach, 384 U.S. at 651.

175. See supra text accompanying notes 160-166.

176. This was particularly true in the context of the Thirteenth Amendment. See supra note 151. But the Court also suggested a similar conclusion in the context of the Fourteenth Amendment. See supra note 152 and accompanying text.

177. Bd. of Trs. of Univ. of Ala. v. Garrett, 531 U.S. 356, 377 (2001) (Breyer, J., dissenting).

178. 42 U.S.C. $§ 12,101(\mathrm{a})(7)$, (9) (2000). 
expression to our most basic ideals of freedom and equality." 179

The Katzenbach approach authorized Congress to conclude that these ideals were so precious and so threatened as to merit legislation based upon Section 5 power. At the same time, however, the Katzenbach approach left the Court entirely free to wrestle with its own ambivalence about the constitutional status of disabled persons, as reflected in its roughly contemporaneous opinion in City of Cleburne v. Cleburne Living Center, ${ }^{180}$ which simultaneously announced a rational basis standard of review and engaged in elevated scrutiny. ${ }^{181}$ After Katzenbach the Court might have upheld the ADA by simply deferring to Congress's judgment that the statute was needed to redress constitutional injuries under Section 5. Even after Boerne, moreover, the Court could have upheld the ADA by independently concluding that extensive congressional fact finding had demonstrated that the ADA was a congruent and proportional way of preventing or deterring the harms of invidious discrimination which the Court itself had deemed unconstitutional. ${ }^{182}$ But in Garrett the Court repudiated these various methods of decoupling Section 5 legislation from judicial enforcement of Section 1. Instead it has advanced a test that effectively requires evidence of judicially redressible violations of Section 1 before Congress can exercise its Section 5 power.

By tightly binding the exercise of Section 5 power to judicial enforcement of Section 1, Garrett effectively undercuts the many civil rights statutes which Congress has enacted in response to the Court's own invitation in Katzenbach. ${ }^{183}$ Garrett disavows the Court's responsibility for encouraging this legislation. What is lost in

179. Statement on Signing the Americans with Disabilities Act of 1990, 26 WEEKLY COMP. PRES. DoC. 1165 (July 26, 1990).

180.473 U.S. 432 (1985).

181. Id. at 458-59 (Marshall, J., concurring in part and dissenting in part). See William Christian, Normalization as $a$ Goal: The Americans With Disabilities Act and Individuals With Mental Retardation, 73 TEX. L. REv. 409, 423 (1994); Comment, Cleburne: An Evolutionary Step in Equal Protection Analysis, 46 MD. L. REV. 163, 185-89 (1986).

182. See City of Boerne v. Flores, 521 U.S. 507, 518 (1997). This is essentially the tack taken by the Eleventh Circuit in upholding, under Section 5, the application of the disparate impact provisions of Title VII to the states. See Crum v. Alabama (In re Employment Discrimination Litig. Against Alabama), 198 F.3d 1305, 1322 (11 th Cir. 1999). See also Holmes v. AFSCME Ind. Council 52, 70 U.S.L.W. 1491 (S.D. Ind. 2002).

183. We note that it is one thing for the Court in Kimel v. Fla. Bd. of Regents, 528 U.S. 62 (2000), to hold that Congress is without power under Section 5 to enact the Fair Labor Standards Act of 1974 ("FLSA"), Pub. L. No. 93-259, $\$ 28,88$ Stat. 55, 74, which extended the protections of the Age Discrimination in Employment Act of 1967 ("ADEA"), 29 U.S.C. \$§ 621-634 (1994 \& Supp. III 1997), to the states. The FLSA "nowhere states that Congress was acting pursuant to its power to enforce the Fourteenth Amendment." EEOC v. Wyoming, 514 F. Supp. 595, 600 (D. Wy. 1981), rev'd, 460 U.S. 226 (1983). See EEOC v. Wyoming, 460 U.S. 226, 244 n.18 (1983). It is quite another for the Court to hold in Garrett that Congress is without power under Section 5 to enact the ADA, when the ADA itself announces that its "purpose" is "to invoke the sweep of congressional authority, including the power to enforce the fourteenth amendment ..." 42 U.S.C. $\S 12,101(\mathrm{~b})(4)$. Garrett, unlike Kimel, suppresses a fully deliberate and explicit congressional decision to employ Section 5 authority, and thereby to give practical meaning to constitutional rights. Congress's effort in the ADA to enforce Section 1 of the Fourteenth Amendment was directly responsive to the constitutional regime established by the Court in Katzenbach. 
such circumstances is precisely Congress's historical capacity to mediate between the constitutional understandings of the judiciary and those of the nation. The ambiguity created by the Katzenbach approach had allowed the contradictory and often tensionfilled relationship between political self-determination and the rule of law to persist without either perspective stifling the other. By eliminating this ambiguity and requiring Congress to speak only in the voice of a court, Garrett is attempting to disable an important mechanism by which the nation maintains democratic dialogue with its judicially enforced Constitution. This is an historical development of enormous significance.

How, then, can Congress respond to this assault? Of course Congress can draft and redraft legislation in an effort to respond to the shifting and ever more exacting standards of the Court's evolving Section 5 jurisprudence. ${ }^{184}$ It would no doubt be wise

184. The constitutionality of Title II of the ADA, for example, represents a virtual law school exam of the diverse difficulties faced by contemporary legislation because of the Court's recent precedents. For example, it must be determined whether Title II of the ADA is a valid exercise of Section 5 power, compare Garcia v. S.U.N.Y. Health Sciences Ctr. of Brooklyn, 280 F.3d 98 (2d Cir. 2001), with Reickenbacker v. Foster, 274 F.3d 974 (5th Cir. 2001), Alsbrook v. City of Maumelle, 184 F.3d 999 (8th Cir. 1999), Wroncy v. Or. Dep't of Transp., 9 Fed. Appx. 604, 606 (9th Cir. 2001), and Thompson v. Colorado, 258 F.3d 1241, 1253 (10th Cir. 2001); whether it is valid under the Commerce Clause when applied to local prisons in a way that may not "substantially" affect interstate commerce, Pierce v. King, 918 F. Supp. 932 (E.D. N.C. 1996), aff d 131 F.3d 136 (4th Cir. 1997), vacated and remanded, 525 U.S. 802 (1998); whether it is a valid exercise of Section 5 power if applied to violations of the equal protection clause "motivated by discriminatory animus or ill will based on the plaintiff's disability," Garcia, 280 F.3d at 112, or to violations of the Due Process clause, Popovich v. Cuyahoga County Ct. Com. Pl., 276 F.3d 808, 815 (6th Cir. 2002); or to violations of "fundamental rights" like voting, Thompson v. Colorado, 258 F.3d 1241, 1252-53 (10th Cir. 2001). Moreover, because Title II addresses only public entities, one may ask whether it is constitutional under the Tenth Amendment due to the fact that it "regulates the States exclusively" and is not a "generally applicable" law. Reno v. Condon, 528 U.S. 141, 151 (2000). Finally, the substantive provisions of Title II are virtually identical to those contained in $\S 504$ of the Rehabilitation Act of 1973,29 U.S.C. $\S 794$ (2000); see H.R. REP. No. 101-485, pt. 2, at 84 (1990), which imposes federal prohibitions of discrimination against disabled persons as a condition for the receipt of federal funds. Section 504 thus raises the question of whether Congress can deploy its spending power "to achieve objectives with respect to the states that it otherwise could not achieve using its other Article I enumerated powers." Celestine Richards McConville, Federal Funding Conditions: Bursting Through the Dole Loopholes, 4 CHAP. L. REv. 163, 164 (2001). Compare Armstrong v. Davis, 275 F.3d 849, $878-79$ (9th Cir. 2001), Douglas v. Cal. Dep't of Youth Auth., 271 F.3d 812 (9th Cir. 2001), Nihiser v. Ohio Envtl. Prot. Agency, 269 F.3d 626 (6th Cir. 2001), Jim C. v. United States, 235 F.3d 1079 (8th Cir. 2000), and Johnson v. Louisiana, No. 01-2002, 2002 WL 83645 (E.D. La. Jan. 18, 2002), with Garcia, 280 F.3d at 112-14, and Koslow v. Pennsylvania, 158 F. Supp 2d 539 (E.D. Pa. 2001). For recent discussion on the spending power, see Lynn A. Baker, Conditional Federal Spending After Lopez, 95 CoLUM. L. REV. 1911 (1995); Lynn A. Baker, Conditional Federal Spending and States 'Rights, 574 ANNALS AM. ACAD. POL. \& SoC. SCI. 104 (2001); Lynn A. Baker, The Spending Power and Federalist Revival, 4 CHAP. L. REV. 195 (2001); Ann Carey Juliano, The More You Spend, the More You Save: Can the Spending Clause Save Federal Anti-Discrimination Laws? 46 VILL. L. REv. 1111 (2001); Michael Selmi, Remedying Societal Discrimination Through the Spending Power, 80 N.C. L. REV. 1575 (2002); 
for Congress to make efforts in this direction. It can attempt to find the factual predicates required by Garrett, or it can sidestep Section 5 altogether and utilize its powers under the Spending Clause or what remains of its commerce power. The question, however, is whether it is sufficient for Congress merely to respond in this fashion.

We suggest that it is not. The Court's recent jurisprudence puts directly in issue the roles that Congress and the Court can play in enforcing the Constitution. It is this question that Congress must self-consciously address. The Court claims authority to interpret the Constitution, and, so long as we have a functioning legal system that merits respect, such authority must be granted. But because the Constitution also lives as the political heritage of the entire nation, the Court's claim to exclusive interpretive authority has implications that far transcend the professional boundaries of the legal system. Although the Court may claim authority to speak for the Constitution, that authority does not exist merely by decree. It must be earned by articulating a vision of the Constitution that the nation is prepared to accept.

Seeking to overturn entrenched practices of the American constitutional tradition, Garrett explicitly denies that Congress plays any role in articulating constitutional understandings. It is to this core challenge-advanced by the Court with increasing stridency in case after case since Boerne-that Congress must respond. The four dissenting Justices in the Court's Section 5 cases are struggling, ever more cogently, to summon a vision of the constitutional regime the majority is now engaged in dismantling. But the dissenting Justices can only do so much. Congress itself must begin systematically to answer the Court's claims.

Yet for Congress to speak back to the Court is no simple matter. At present, Congress seems disengaged and possibly confused. ${ }^{185}$ Although the Court's constitutional claims are far-reaching and highly significant, the Court has, with the exception of Boerne, invalidated only carefully selected and narrow bits of legislation. The Court speaks loudly, but strikes narrowly. Many on the Hill have no special commitment to the provisions of the ADA or the Violence Against Women Act ${ }^{186}$ or the $\mathrm{ADEA}^{187}$ invalidated in recent cases; some may even think the nation better off without the particular provisions invalidated by the Court. No doubt also the very ambiguities of the Katzenbach regime have left members of Congress confused about their proper responsibility as interpreters of constitutional meaning. Given the persistently uncertain status of the many civil rights statutes enacted in the decades after Brown, Congress, like the legal academy, may well be struggling to make sense of the deep questions of constitutional role and structure at stake in the Court's recent decisions. ${ }^{188}$

Rebecca E. Zietlow, Federalism's Paradox: The Spending Power and Waiver of Sovereign Immunity, 37 WAKE FOREST L. REv. 141 (2002).

185. See Neal Devins, Congress as Culprit: How Lawmakers Spurred on the Court's AntiCongress Crusade, 51 DUKE L.J. 435 (2001).

186. See United States v. Morrison, 529 U.S. 598 (2000).

187. See Kimel v. Fla. Bd. of Regents, 528 U.S. 62 (2000).

188. We should stress that Garrett poses a challenge to Congress that is not merely partisan in nature. The ADA was enacted with "strong bipartisan support." See Larry E. Craig, The Americans with Disabilities Act: Prologue, Promise, Produce, and Performance, 35 IDAHO L. REv. 205, 209 (1999); Sweeping Law for Rights of Disabled, 46 CONG. Q. ALMANAC 447 
For decades now, Congress has been legislating to secure Americans protection against discrimination, bringing to bear on this question the nation's evolving judgments and experiences concerning the meaning of rationality and fairness. ${ }^{189}$ Congress can draw on these decades of institutional experience to defend the distinctive ways in which legislatures make judgments about the meaning of invidious discrimination. Congress has enacted numerous federal civil rights statutes pursuant to Section 5 through which the nation now fundamentally defines itself. These statutes address such diverse concerns as voting, employment, housing, education, and violence. As Congress reviews this extraordinary history, it can begin to recover a sense of the myriad ways in which Congress itself has in the past vindicated constitutional values.

In deploying its Section 5 authority to protect civil rights, Congress was acting on a mandate that the American people have not yet retracted. We do not understand the Court's new vision of separation of powers to rest on any equivalent mandate. The juricentric Constitution of Garrett stands on quite different footing than the Court's federalism jurisprudence. The past few Republican presidents have in part campaigned on the need to resurrect respect for the values of federalism. ${ }^{190}$ But no presidential candidate has campaigned on the need to curtail congressional authority to interpret the Constitution, much less on the need to circumscribe the power of the federal government to combat discrimination. Both the ADA and RFRA were in fact highly popular bipartisan statutes. ${ }^{191}$

Ultimately the Court's aggressive new vision of the juricentric Constitution will be tested in the crucible of public understanding. The Court may assert that it possesses the exclusive prerogative to interpret the Constitution, but in the final analysis it shares that authority with the American people. A constitutional crisis would surely result were the Court to insist on pushing its new vision of separation of powers to impose

(1990). And even if we might be tempted now to dismiss the ADA as merely a "liberal" statute, toward which a conservative Court might naturally express hostility, RFRA, which the Court struck down in Boerne, was a statute that generated and continues to generate strong support from both the left and the right. See Conkle, supra note 94, at 88-89; Religious Freedom Bill Wins Quick Passage, 49 CONG. Q. ALMANAC, 315 (1993); Bonnie I. Robin-Vegeer, Disposing of the Red Herrings: A Defense of the Religious Freedom Restoration Act, 69 S. CAL. L. REV. 589, 591 n.2 (1996); Robert W. Tuttle, How Firm a Foundation? Protecting Religious Land Uses After Boerne, 68 Geo. WASH. L. REv. 861, 863-64 (2000). The Patent and Plant Variety Protection Act Remedy Clarification Act, Pub. L. 102-560, 106 Stat 4230 (1992), which was struck down in Florida Prepaid Postsecondary Education Expense Board v. College Savings Bank, 527 U.S. 627 (1999), was also bipartisan and widely supported. See S. REP. No. 102-280, at 2 (1992), reprinted in 1992 U.S.C.C.A.N. 3087, 3088; 138 CONG. REC. S. 8146-03 (1992); 138 CONG. REC. H. 11131-03 (1992). A recent bipartisan bill has been introduced in order to revive the Act. See Intellectual Property Restoration Act of 2002, S. 2031, 107th Cong. (2002). In Dickerson v. United States, 530 U.S. 428 (2000), moreover, the Court struck down a statute that represented an unabashedly conservative initiative. See 18 U.S.C. $\$ 3501$ (2000). The root question of the juricentric Constitution, therefore, concerns Congress's constitutional role as a coordinate branch of the federal government.

189. See Stephen M. Griffin, Judicial Supremacy and Equal Protection in a Democracy of Rights, 4 U. PA. J. CONST. L. 281, 284-87 (2002).

190. See supra note 106.

191. See supra note 188. 
categorical restrictions on Congress that directly and fundamentally challenge popular convictions concerning the necessary scope of national power. In the absence of such a crisis, however, popular resistance to the slow and nearly imperceptible erosion of congressional authority will depend upon congressional leadership. If Congress wishes to reclaim its prerogatives as an equal and coordinate branch of the federal government, it must counter the Court's claims of exclusive authority with a public and persuasive defense of Congress's historical role in the creation of constitutional meaning. It must act to protect the Constitution for the people. 
HeinOnline -- 78 Ind. L.J. 462003 